\title{
Osmanlı Devleti'nin Son Döneminde Süryani Kilisesi ve Süryanilerin İdaresi
}

\author{
Ramazan Erhan Güllü*
}

The Syriac Orthodox Church in the Late Period of Ottoman State and the Administration of the Syriac Orthodox Community

Abstract $\square$ The Syriac Orthodox Community in the Ottoman State were administratively affiliated with the Armenian Patriarchate. Only the Greeks, Armenians and Jews were accepted as non-Muslim nations in the millet system organized by Fatih Sultan Mehmet after the conquest of Istanbul. Other Christian groups except for the Greeks and the Armenians were administratively linked to the Greek or Armenian Patriarchate. The Syriac Orthodox Community were in charge of the Armenian Patriarchate. This administrative structure continued until the 19th century. Hereafter the classical millet system would undergo change. The state began to recognize some Christian communities other than the Greek, Armenian and Jewish as separate millets, and to give the existing millets some constitutional rights different from previous periods. The Syriac Orthodox Community failed to achieve such a right in this period. In the mid-19th century, they opened their own agency in Istanbul to carry out their relations directly with the state. Yet, this would not mean that the Syrians would perform their relations directly with the state. The Armenian Patriarchate was still an intermediary between The Syriac Orthodox Community and the state. This caused various problems with the Armenian Patriarchate and the Armenian millet, leading to struggles between the Armenian and Syriac Orthodox communities. The Syriac Orthodox Community officially applied for the right to be recognized as a separate millet under their own name in 1914, just like other non-Muslim millets living in the Ottoman State. With The Süryani Kadìm Milleti Nizamnamesi, the Syriac Orthodox community appealed for the constitutional rights which were acquired by the Greek, Armenian and Jewish millets 50 years ago. In this paper, the administrative process

* İstanbul Üniversitesi.

Bu makale, İstanbul Üniversitesi Bilimsel Araştırma Projeleri Birimi (BAP) tarafından “BEK-2017-26530” proje kodu ile desteklenmiştir. 
experienced by the Syriac Orthodox millet under the Ottoman administration, the negative effects of Syriac Orthodox's affiliation to the Armenian Patriarchate, the attempts to leave the Patriarchate, the Armenian - Syriac Orthodox strife experienced during these efforts and the statute demanded in 1914 will be examined. Through a detailed analysis of the contents of the "Nizamname", the similarities and differences between the "Nizamname"s of the other non-Muslim millets will be shown.

Keywords: Ottoman Millet System, The Syriac Orthodox Community, Armenian Patriarchate, First World War.

\section{Giriş}

Osmanlı Devleti'nin tebaası olan gayrimüslim topluluklar, sonraları "Osmanlı Millet Sistemi” olarak adlandırılan bir hukuki yapı çerçevesinde yönetilmekteydiler. Bu yapıda, "millet" kelimesi bir ırkı değil, bir dine/mezhebe inananları tanımlamaktaydı. İstanbul'un fethi sonrası teşkilatlandırılmaya başlanıp, sonraki tarihlerde Osmanlı yönetimi altına giren yeni bölgelerde yaşayan gayrimüslim toplulukların da dâhil edildiği bu idari yapılanmada gayrimüslim Osmanlı vatandaşları üç millete ayrılmaktaydı: Yahudi, Rum ve Ermeni milletleri. Buna karşılık Müslümanlar da etnik veya mezhepsel farklılıkları dikkate alınmadan tek millet olarak kabul edilmekteydi. Gayrimüslimleri, başkent İstanbul'da dini temsilcileri bulunan (Rum ve Ermeni patrikhaneleri ile Yahudi Hahambaşılığı) üç dinî millete ayırarak devlet, merkezî otoritesini kuvvetlendirdiğini düşünüyordu. Gayrimüslimler ile ilgili meselelerde devletin kendisine muhatap olarak kabul ettiği merciiler, başkentteki bu dini kurumlar ve onların yetkilileriydi. Ahalinin idaresi ve devlete karşı sorumlulukları da (vergi ödeme vs) bu kurumlar aracılığıyla yapılmaktaydı. ${ }^{1}$ Dolayısıyla bu yapı içerisinde Hristiyanlar, Rumlar ve Ermeniler olmak üzere iki millet üzerinden temsil edilmekteydiler. Etnik olarak Rum veya

1 Osmanlı Devleti'nin gayrimüslimlerle ilgili uygulamalarını Millet Sistemi olarak tanımlamak yerine bu uygulamaları İltizam Sistemi içerisinde değerlendirmek gerektiğini ifade eden çalışmalar bulunmaktadır. Paraskevas Konortas, "İstanbul Rum-Ortodoks Patrikhanesi ile Osmanlı Yönetiminin Birlikte Yaşamı (1453-1923)”, İdea Politika, 4 (Güz 1999), s. 6472.; Paraskevas Konortas, “Tarihi Uzlaşma'dan Entente Cordial'e?: İstanbul Ortodoks Patrikhanesi ile Osmanlı İdaresi Arasında İdeolojik ve Siyasi Amaç Birliği (15. Yüzyıl Ortası - 16. Yüzyıl Sonu)", çev. Yaman Aksu, Tarihî, Siyasi, Dinî ve Hukuki Açıdan Ekümenik Patrikhane, ed. Cengiz Aktar (İstanbul: İletişim Yayınları, 2011), s. 27-69. İltizam sistemi tanımı ve değerlendirmesi hakkında daha kapsamlı ve önemli bir çalışma için bkz. M. Macit Kenanoğlu, Osmanlı Millet Sistemi - Mit ve Gerçek (İstanbul: Klasik Yayınları, 2007). Ayrıca sistemle ilgili farklı görüşlerin tartışıldığı eleştirel bir çalışma için bkz. Benjamin Braude, "Foundation Myths of the Millet System", Christians and Jews in the Ottoman Empire: The 
Ermeni olmayan Hristiyan topluluklar da inançlarının benzerliği, bulundukları coğrafyada bir arada yaşadıkları diğer topluluklar ve gayrimüslim milletlere ait dinî/siyasi kurumlara yakınlık gibi unsurlar dikkate alınarak, bu iki Hristiyan milletten birisinin içerisinde değerlendiriliyorlardı. Bu anlamda da genel olarak Ortodoks Hristiyanlar Rum milletine tâbi kabul edilip Rum Patrikhanesi'ne bağlı sayılsalar da Ortodoks olan Süryaniler, Ermeni milletine tâbi kabul edilerek Ermeni Patrikhanesi'ne bağlanmışlardı. Zira Süryaniler, Ermenilerle aynı coğrafyada yaşamakta ve Monofizit Hristiyan itikadında olduklarından dolayı inanç olarak Ortodoks Rumlardan ziyade Ermenilere yakın bulunmaktaydılar. ${ }^{2}$

\section{Süryanilerin ve Süryani Patrikhanesi'nin Osmanlı İdaresine Girişi ve İdarî Durumları}

Kendilerini Babil ve Asur toplumlarının devamı olarak tanımlayan Süryaniler, Hristiyan inancına geçiş sonrası "Süryani" olarak isimlendirildiklerini belirtmektedirler. Dolayısıyla Süryani ismi etnik bir tanımlamadan ziyade dinî bir topluluğu ifade eden bir kavram olarak ortaya çıkmışsa da zamanla Süryaniler ayrı bir etnik topluluk olarak da tanımlanmaya başlanmışlardır. ${ }^{3}$ Süryani Kilisesi de Havari Petrus tarafindan kurulan "apostolik" bir kilise olarak kabul edilmektedir. Havari Petrus tarafından Antakya'da kurulduğuna inanılan Süryani Kilisesi yüzyıllarca Antakya'da varlığını sürdürmüş ve patrikhane merkezi buradan taşındıktan sonra dahi Süryani Patrikhanesi "Antakya Patrikliği” olarak anılmıştır. Bu isimlendirme Osmanlı döneminden günümüze kadar da aynı şekilde devam etmiştir. ${ }^{4}$

Ağırlıklı olarak Irak ve civarında yaşayan Süryaniler, özellikle Bizans’ın bölgeye egemen olduğu dönemde sert politikalara maruz kalmışlardı. Bu politikalardan

Functioning of a Plural Society, c. I: The Central Lands, ed. Benjamin Braude, Bernard Lewis (New York - London: Holmes \& Meier Publishers, 1982), s. 69-88.

2 Canan Seyfeli, “Osmanlı Devleti’nde Gayrimüslimlerin İdari Yapısı: Süryani Kadim Kilisesi Örneği”, Süryaniler ve Süryanilik - I. Kitap, haz. Ahmet Taşğın, Eyyüp Tanrıverdi, Canan Seyfeli (Ankara: Orient Yayınları, 2005), s. 254-261.

3 Süryanilerin kökeni ve tarihî süreçte hangi isimlerle tanımlandıklarına dâir hususlar için bkz. Gökhan Sarı, Ermeni Meselesi Işı̆ğında Süryaniler: Tartı̧̧ılan Bir Köken, Eleştirilen Bir Politika ve Unutulan Bir Değer (Ankara: Barış Kitabevi, 2013), s. 22-50; Simo Parpola, "National and Ethnic Identity in the Neo-Assyrian Empire and Assyrian Identity in Post-Empire Times", Journal of Assyrian Academic Studies, 18/2 (2004), s. 5-49.

4 Aziz Günel, Türk Süryaniler Tarihi (Diyarbakır: y. y., 1970), s. 83-84; Yakup Bilge, Geçmişten Günümüze Süryaniler (İstanbul: Zvi-Geyik Yayınları, 2001), s. 73-79. 
kilise de etkilenmiş, Bizans’ın kendilerine yönelik sert tavırları dolayısıyla Süryaniler patriklik merkezini 11. yüzyıla doğru Malatya yakınlarındaki Mor Barsavmo Manastırı'na taşımışlardı. 1166 yılında patrik olan Mor Mihoyel Rabo tarafından patriklik merkezinin değiştirilmesiyle ilgili çalışmalar başlatılmış, ne var ki bu ancak 13. yüzyıl sonlarında (muhtemelen 1293 yılında, Patrik Bin Vahap döneminde) mümkün olabilmişti. Bu tarihte patriklik merkezi, Mardin'de bulunan ve uzun yıllardır Süryani Patrikhanesi’ne bağlı bir metropolitlik vazifesi gören Deyru'z-zafaran Manastırı'na taşınmıştı. Deyru'z-zafaran Manastırı'nın patriklik merkezi olduğu dönemde Mardin ve civarı Selçuklu Devleti'nin egemenliği altında bulunmaktaydı. Süryanilerin ve Süryani Patrikhanesi'nin Osmanlı idarî sistemine dâhil olmaları ise Yavuz Sultan Selim döneminde Suriye, Kudüs ve Mısır civarının alınması sonrası gerçekleşmişti. Süryanilerin yoğun olarak yaşadıkları bölgelerin Osmanlı idaresine dâhil olmasıyla birlikte Deyru’z-zafaran Manastırı da patrikhane merkezi olmaya devam etmiş, statüsüne dokunulmamış, aynı işlevleri yürütmüştür. ${ }^{5}$

Yavuz Sultan Selim Kudüs'ü fethettikten sonra Kudüs Ermeni Patriği III. Serkis'e verdiği bir fermanla Ermenilere yeni bazı haklar tanımış, kendilerine ait kilise, manastır ve diğer emlâki kullanmaya devam edeceklerini belirtmiş ve Kudüs'teki kutsal yerlerin statüsü ile ilgili bir takım hükümler vermişti. Ayrıca Kudüs'te bulunan Habeş, Kuptî ve Süryani ahalileri Kudüs Ermeni Patrikhanesi'ne bağlı olacaklardı. İlerleyen yıllarda Kudüs Ermeni Patrikhanesi zaten İstanbul Ermeni Patrikhanesi'nin idaresinde faaliyet yürüteceği gibi Yavuz'un Patrik Serkis’e verdiği haklar benzer şekilde İstanbul patriklerince de kullanılacaktı. Bununla beraber Habeş, Süryani ve Kıptî kiliseleri bazı dönemlerde Rum Patrikhanesi'ne bağlı hâle getirileceklerdi. Bu durum İstanbul'da Rum ve Ermeni Patrikhaneleri arasında çatışmalara neden olduğu gibi, patrikhaneler bu konu üzerinden

5 P. Gabriyel Akyüz, Deyrulzafaran Manastırinın Tarihi (İstanbul: Resim Ofset - Matbaacılık A. Ş., 1998), s. 34-36; P. Gabriyel Akyüz, Mardin İlinin Merkezinde, Civar Köylerinde ve İlçelerinde Bulunan Kiliselerin ve Manastırların Tarihi (İstanbul: Resim Ofset - Matbaacılık A. Ş., 1998), s. 58.; Samuel Akdemir, "Geçmişte ve Günümüzde Türkiye'deki Süryani Kilisesi”, Dinler Tarihi Araştırmaları - III (Sempozyum, 09-10 Haziran 2001, Ankara), Hiristiyanlık (Dünü, Bugünü ve Geleceği) (Ankara: Dinler Tarihi Derneği Yayınları, 2002), s. 10. Sonraki Süryani patriklerinden olan Hanna Dolabani, patriklik merkezinin Deyru'z-zafaran'a taşınmasının Patrik Mor Mihoyel Rabo döneminde gerçekleştiğini belirtir. Hanna Dolabani, Antakya Süryani Kadim (Ortodoks) Patriklerinin Özgeçmişi, çev. Gabriyel Akyüz, ed. İbrahim Özcoşar, Hüseyin H. Güneş (İstanbul: Mardin Tarihi İhtisas Kütüphanesi Yayını, 2006), s. 4. 
otoritelerini güçlü tutma mücadelesine girişeceklerdi. Bunlarla birlikte bu üç toplumun idaresi çoğunlukla Ermeni Patrikliği'ne bağlı olarak sürdürülecekti. ${ }^{6}$ Özellikle 19. yüzyılda durum bu şekilde olacaktı. Bu toplulukların Ermeni Patrikhanesi'ne bağlı olmalarının temel nedeni Osmanlı Devleti'nin merkeziyetçi anlayışı olmakla birlikte dinî olarak da bu grupların tamamının Kadıköy Konsili kararlarına karşı çıkan Monofizit anlayışta olmaları, kendi kiliseleri içinde ciddi parçalanmışlıklar bulunması gibi farklı nedenler de bulunmaktaydı. ${ }^{?}$

Yeni bazı düzenlemelerle birlikte Osmanlı idaresinde Süryani Patrikhanesi'nin dinî otorite alanı, eskiden olduğu şekliyle korunmuştu. Deyru'z-zafaran Manastırı merkezli Süryani Patrikhanesi, Süryanilerin yoğun olarak yaşadıkları Diyarbakır ve Halep vilâyetlerine dâhil bölgelerle birlikte Şam, Rakka, Musul, Mardin vilâyet ve sancaklarıyla Hindistan'da yaşayan Süryanilerin de bağlı oldukları dinî kurumdu. Dolayısıyla Osmanlı sınırları dışında kalan bazı bölgelerde de (yoğun olarak Hindistan'da) patrikliğe ruhani olarak bağlı olan ahali bulunmaktaydı. Patrikliğin fahrî makamı Deyru'z-zafaran Manastırı iken, cemaatin ruhani ve idârî işleri ise manastıra bağlı Kırklar Kilisesi’nden yönetilmekteydi. Fakat Süryaniler, yukarıda da bahsedildiği şekilde, Osmanlı Devleti tarafından resmî işlerinde ayrı bir millet olarak tanınmadıklarından, Ermeni Patrikhanesi'nin sorumluluğunda ve Ermeni milletine tâbi olarak kabul edilmişlerdi. Bu yüzden Osmanlı Devleti'nin resmî yazışmalarında Süryanilerden, "Süryani Ermenileri", "Ermeni yamakları" veya "Ermeni milletinin Süryani tâifesi” olarak bahsedilmekteydi. Bu durum Süryani Patrikhanesi'nin kendi içindeki idari ve ruhani yapısında bir değişikliğe neden olmamıştı. Ruhani anlamda bağımsız olan Süryani Patrikhanesi ve ona bağlı kiliseler ayin ve ibadetlerini kendi usüllerine göre yapmaktaydılar. Süryanilerin ruhani hayatlarını rahatça sürdürmelerinden ve devleti ilgilendiren tüm işlerini yürütmelerinden Ermeni Patrikhanesi sorumlu idi. Ayrıca Süryani ruhanilerin seçimleri, tayin ve azilleri, kilise ve manastırlarının tamiri gibi meseleleri de Süryani Patrikhanesi, Bâb-1 Âlî̀ye Ermeni Patrikhanesi aracilığıyla bildirebiliyordu. ${ }^{8}$

6 Yavuz Ercan, Kudüs Ermeni Patrikhanesi (Ankara: Türk Tarih Kurumu Yayınları, 1988), s. $15-21$.

7 İbrahim Özcoşar, Bir Yüzyıl Bir Sancak Bir Cemaat: 19. Yüzyılda Mardin Süryanileri (İstanbul: Beyan Yayınları, 2008), s. 57-62.

8 Seyfeli, “Osmanlı Devleti’nde Gayrimüslimlerin İdari Yapısı”, s. 262; Özcoşar, Bir Yüzyıl Bir Sancak Bir Cemaat, s. 52-62; İbrahim Özcoşar, "Osmanlı Devleti’nde Millet Sistemi ve Süryani Kadimler”, Süryaniler ve Süryanilik - II. Kitap, haz. Ahmet Taşğın, Eyyüp Tanrıverdi, Canan Seyfeli (Ankara: Orient Yayınları, 2005), s. 209-237; Deniz Bayburt, 
Süryanilerin, Ermeni Patrikhanesi'nin sorumluluğuna bırakılmalarında, iki toplum arasındaki inanç yakınlığı kadar aynı ya da yakın bölgelerde yaşamaları da etkili olmuştu. Gayrimüslim tebaasının idaresinde muhatap makamı olarak sadece başkent İstanbul'daki dini kurumları ve onların yetkililerini görmek isteyen Osmanlı Devleti, bu politikasını Süryanileri Ermeni Patrikhanesi’ne bağlayarak devam ettirmiş oluyordu. Süryanilerin yoğun olarak yaşadıkları bölgelerin Osmanlı yönetimine girişinden itibaren idareleri bu şekilde sürdürülmekle birlikte Süryaniler bu politikayı baştan itibaren kabullenmek istememişlerdi. Ermenilerin Süryaniler üzerinde, örneğin Rumların Bulgarlara karşı yaptığı gibi, ${ }^{9}$ yoğun dinî ve kültürel baskıları söz konusu değildi. Buna rağmen Süryaniler, Ermeni Patrikhanesi'nin idaresinden çımak, doğrudan bunu başaramasalar dahi en azından başkent İstanbul'da kendilerine ait bir idarî makama sahip olabilmek için sürekli uğraşmışlardı. Ancak Tanzimat dönemine kadar bu amaçlarına ulaşamamışlardı. Fakat Süryaniler taleplerini elde edebilmek için uğraşmaya devam edecekler hatta Süryani patrikleri çoğu zaman Deyru'z-zafaran Manastırı'nda değil Mardin Sancağı'nın bağlı olduğu vilâyet merkezi olan Diyarbakır'da ikamet ederek en azından bölgedeki yerel yetkililerle doğrudan muhatap olmak isteyeceklerdi. Vilayet idaresinde etkin olunursa bunun başkente de yansıyacağı ve Ermenilerden ayrılma taleplerine daha kolay ulaşabilecekleri düşünülmekteydi. ${ }^{10}$ Süryanilerin Ermeni Patrikhanesi'ne yönelik en büyük eleştirileri, kendilerinin de Ermeni milletine tâbi oldukları gerekçesiyle patrikhanenin Süryanileri nüfus kayıtlarına Ermeni olarak kaydettirdiğine dairdi. Buna bağlı olarak da Süryani kimliğinin yok sayıldığı düşünülmekteydi. Kimlik ve millet tartışmaları dışında iki toplumun en fazla ihtilaflı oldukları mevzu ise bazı arazi ve kilise mallarının kime ait olduğu ile ilgiliydi. Bu mevzuyla ilgili tartışmalar uzun zaman devam edecek ve birçok yerle ilgili hak talepleri net bir sonuca kavuşamayacaktı. Ayrıca Süryaniler benzer bir mal-mülk çatışmasını Kürtlerle de yaşamaktaydılar. Özellikle bazı

“Türk Tarihi'nde Süryaniler (1880-1938)" (doktora tezi), Gazi Üniversitesi Sosyal Bilimler Enstitüsü, 2009, s. 32-33.

9 Rum Patrikhanesi, kendisine bağlı olan diğer Ortodoks topluluklar - özellikle de Bulgarlar üzerinde ciddi bir hegemonyaya sahipti. İbadetten kilise okullarındaki eğitime kadar birçok alanda Rumcayı Bulgarlar için zorunlu hale getirmeye çalışan patrikhaneye karşı Bulgarlar uzun zaman kendilerine yönelik asimilasyon siyaseti izlediği gerekçesiyle karşı olmuşlardı. Patrikhaneye bağlı olmaktan kurtulmak ve kendi kilise merkezlerine sahip olmak isteyen Bulgarlar, 1870 yılında Bulgar Eksarhlığı'nın tesisi ile bu taleplerini elde etmeyi başarmışlardı. Ramazan Erhan Güllü, "Bulgar Eksarhlığı'nın Kuruluşu ve Statüsü”, Gaziantep Üniversitesi Sosyal Bilimler Dergisi (GAUN-JSS), 17/1 (2018), s. 350-361.

10 Özcoşar, Bir Yüzyıl Bir Sancak Bir Cemaat, s. 84. 
Süryanilerin göçleri neticesinde Kürtlerin birçok Süryani mülkünü sahiplendikleri ifade edilmekteydi. ${ }^{11}$

Ermeniler ve Ermeni Patrikhanesi ile yaşanan bu tür çatışmaların da etkisiyle Süryaniler kendilerinin de İstanbul'da bir yetkili makama sahip olmalarını ve devletle Ermeni Patrikhanesi aracıllı̆̆ıla değil de doğrudan kendileri tarafından seçilmiş bir yetkili ile muhatap olmalarının sağlanmasını istiyorlardı. Tanzimat dönemine kadar İstanbul'da bu tür bir makam açılması devlet tarafından kabul edilmemişti. Tanzimat Fermanı sonrası getirilen yeni uygulamalarla birlikte İstanbul'da Süryaniler için bir Patrik Vekilliği ihdas edilmiş, böylece Süryaniler uzun zamandır talep ettikleri gibi başkentte Süryani Patrikhanesi adına yetkili bir idarî makama sahip olmuşlardı. Bazı araştırmalarda, vekilliğin ihdas tarihinin 1844 olduğu ifade edilir. ${ }^{12}$ Fakat 1844 yılından önce de İstanbul'da Süryani Patrik Vekilliği'nin varlığı bilinmektedir. Dönemin patriği II. İlyas tarafından, Tanzimat’tan sonra Rahip Behnam İstanbul'a metropolit ve patrik vekili olarak atanmıştı. ${ }^{13} 1844$ yilında da (daha sonra patrik olacak olan) II. Yakup, İstanbul'da Patrik Vekilliği görevine getirilmişti. ${ }^{14}$ Dolayısıyla - tam tarihini tespit etmek mümkün olamadıysa da - vekilliğin ihdasının Tanzimat Fermanı'nın hemen ertesinde gerçekleştiğini söylemek yanlış olmayacaktır. Patrik Vekilliği'nin tesisiyle Süryaniler başkentte bir yetkiliye sahip olmuştu ancak bu durum Süryanilerin artık ayrı bir millet olarak kabulü veya devletle doğrudan temasta bulunabilme hakkına sahip oldukları anlamına gelmemekteydi. Süryaniler için devletle iletişime geçme makamı hâlen Ermeni Patrikhanesi idi. İstanbul'da bulunan Patrik Vekili, resmî işlemlerini yine Ermeni Patrikhanesi aracılığı ile yürütmekteydi. Dolayısıyla İstanbul'da açılan "Patrik Vekilliği", patrikhanenin kendi işlerini kolaylaştırmak adına "cemaat içi bir atama” şeklinde oluşturulan bir yapı idi. Devlet nazarında vekilliğin hiçbir resmî karşıllğı bulunmamaktaydı. Fakat Süryaniler başkentte böyle bir Süryani temsilcinin bulunmasını, en azından gayr-i resmî seviyede devlet tarafından da Süryanilerin varlığının tescili ve bir muhatap makamına sahip oldukları şeklinde yorumlamaktaydilar. ${ }^{15}$

11 Mustafa Çiçek, “Tanzimat Sonrasında Osmanlı Devleti’nde Süryanî Cemaati” (yüksek lisans tezi), Sakarya Üniversitesi Sosyal Bilimler Enstitüsü, 2003, s. 90-93; Sar1, Ermeni Meselesi Işı̆̆ında Süryaniler, s. 209-210.

12 Ebubekir Sofuoğlu, İlke Nur Akvarup, “Osmanlı Devleti’nde Millet Sistemi ve Süryaniler”, Akademik Incelemeler Dergisi, 7/1 (2012), s. 80-81.

13 Dolabani, Antakya Süryani Kadim (Ortodoks) Patriklerinin Özgeçmişi, s. 172-173.

14 Dolabani, Antakya Süryani Kadim (Ortodoks) Patriklerinin Özgeçmişi, s. 177.

15 Seyfeli, “Osmanlı Devleti'nde Gayrimüslimlerin İdari Yapısı", s. 262-263; Bayburt, “Türk 


\section{Misyonerlik Faaliyetleri ve Süryani Patrikhanesi'nden Kopuşlar}

Ermeniler ve Süryaniler arasında var olan sıkıntılar dolayısıyla Ermeni Patrikhanesi ile Süryani Patrikhanesi arasındaki ilişkiler zaman zaman gerginleşmeye devam etse de her iki patrikhanenin ortak tavır aldıkları ve şikâyetçi oldukları en temel konu misyonerlik faaliyetleri idi. Ermeni Patrikhanesi, mezhep değiştiren Ermenilerin kendi otoritesini tanımayacakları gerekçesiyle misyonerlik faaliyetlerine karşıydı. Patrikhane bu konuda ilk ve en ciddi problemleri Katoliklerle yaşamıştı. Ancak patrikhane misyonerlerin Ermeniler arasında yürüttükleri faaliyetlere engel olamayacak ve 1830 yılında Katolik Ermeniler ayrı bir patriklik kurmayı başaracaklardı. ${ }^{16}$ Ermeni Patrikhanesi'nin Katoliklerle ilgili yaşadığı problemleri Süryani Patrikhanesi de benzer şekilde yaşamıştı ve Tanzimat sonrası süreçte de yaşamaya devam etmekteydi. 18. yüzyılda Süryaniler arasında da bir Katolik kitle oluşmuş, 1782 yılında yapılan patrik seçimi sırasında yaşanan ihtilafları kendi lehlerine kullanan Katolikler, Papalığın onayıyla "Süryani Katolik Patrikliği”ni tesis etmişlerdi. Osmanlı Devleti tarafından tanınmayan bu patrikliği, doğrudan Deyru'z-zafaran Manastırı'nda teşekkül ettirerek Süryanilerin tamamını kendilerine bağlamayı hedefleyen Katolikler bu konuda başarılı olamasalar da Süryani Kilisesi’nde yeni bir ayrıllğa neden olmuşlardı. Süryani Katolik Patrikliği'nin merkezi de Halep şehri olmuştu. (Birinci Dünya Savaşı yıllarına kadar Halep’te kalan patriklik merkezi savaştan sonra Halep’ten Beyrut'a taşınmıştır. ${ }^{17}$ )

Tarihi'nde Süryaniler”, s. 38. İbrahim Özcoşar, İstanbul'da ilk resmî Süryani cemaati temsilciliğine 1852 yılında rastlandığını, bu tarihten önce atanan vekillerin, yukarıda ifade ettiğimiz şekilde "cemaat içi atama özelliği taşadığını" belirtir. Özcoşar, Bir Yüzyıl Bir Sancak Bir Cemaat, s. 85; İbrahim Özcoşar, "Osmanlı'da Hristiyan Cemaatler Arası İlişkiler: Ermeni-Süryani Örneği”, Mukaddime, 5/2 (Güz-2014), 2015, s. 7.

16 Kemal Beydilli, II. Mahmut Devri’nde Katolik Ermeni Cemâati ve Kilisesi'nin Tanınması (1830), yay. Şinasi Tekin, Gönül Alpay Tekin (Harvard: Harvard Üniversitesi Yakındoğu Dilleri ve Medeniyetleri Bölümü Yayını, 1995), s. 20-33.

17 Özcoşar, Bir Yüzyıl Bir Sancak Bir Cemaat, s. 98-110; İbrahim Özcoşar, "Papalığın Müdahalesi ve Süryani Kiliselerinde Bölünme: Keldanî ve Süryani Katolik Patriklikleri”, Süryaniler ve Süryanilik - I. Kitap, haz. Ahmet Taşğın, Eyyüp Tanrıverdi, Canan Seyfeli (Ankara: Orient Yayınları, 2005), s. 284-294; İbrahim Özcoşar, "Separation and Conflict: Syriac Jacobites and Syriac Catholics in Mardin in the Eighteenth and Nineteenth Centuries", Byzantine and Modern Greek Studies, 38/2 (2014), s. 207-208; Sarı, Ermeni Meselesi Işı̆̆ında Süryaniler, s. 63-66. Süryanileri doğrudan Katoliklere bağlı hale getirme amacını Katolikler şu şekilde açıklıyorlardı: “[...] Eğer Süryani Ortodokslar kendi geleneklerinin canlı bir tanığı olarak var olmaya devam etmek istiyorlarsa, sorunlarının şu kestirme çözümden, yani aynı anda hem Maruniler'e hem de Katolikler'e katılmaktan başka hiçbir gerçek çözümü yoktur [...]”, 
Süryanilerin yaşadığı bu yeni bölünme sonrası, Süryani Patrikliği’ne bağlı Ortodoks Süryanileri diğerlerinden ayırmak için onlardan artık "Süryani Kadîmler" olarak bahsedilmeye başlanacaktı. (Süryaniler eskiden beri kendilerini "Süryani Yakubiler" olarak da tanımlamaktaydılar. Osmanlı Devleti tarafından zaman zaman bu isim de kullanılmakla beraber çoğunlukla "Süryani Kadîm" ismi kullanılmıştı. ${ }^{18}$ Başlangıçta devlet tarafından tanınmayan Süryani Katolikler, Ermeni Katolik Patrikliği'nin tesisi sonrası bu patrikhaneye bağlanmışlardı. Katolik Süryanilerin, Ermeni Katolik Patrikhanesi'ne bağlılıkları da tıpkı Süryani Kadîmlerin Ermeni Patrikhanesi’ne bağlll l̆ğı gibi olacaktı. Süryani Katoliklerin devletle olan ilişkilerinde muhatap makamları Ermeni Katolik Patrikliği idi. Ancak Katoliklerin misyonerlik faaliyetleri ilerleyen yıllarda da devam edecek, bu durum Ermeniler arasında Katolik mezhebine geçişin devamına neden olduğu gibi "Süryani Kadîmler" arasında da Katolik mezhebine geçişler sürecekti. Her iki patrikhane de Katoliklere karşı tavırlarını aynı şekilde devam ettireceklerdi. Ancak Süryaniler'de Katolikliğe geçiş nüfuslarına oranla daha fazla olmakta hatta bazı dönemlerde "episkopos" seviyesinde üst düzey Süryani din adamlarının dahi Katolikliğe geçişine rastlanmaktayd. ${ }^{19}$ Süryani Kadîmlerle Katolikler arasındaki bu ayrım Birinci Dünya Savaşı yıllarına kadar devam edecekti. Savaş dönemine kadar devlet tarafindan birbirinden farklı toplumlar olarak kabul edilen Katolik ve Kadîm Süryaniler arasındaki ayrımı hükümet savaş sırasında kaldıracak, nüfus cetvellerinde bundan böyle Süryanilerin mezhep ayrımı yapılmadan toplu olarak (sadece Süryani şeklinde) kaydedilmelerini isteyecekti. ${ }^{20}$

Joseph Molitor, Kildaniler ve Doğu Süryani Kilisesi, çev. Erol Sever (İstanbul: Yaba Yayınları, 2004), s. 77.

18 Osmanlı Devleti’nin Süryani Kilisesi'ni resmî organlarında "Süryani Kadîm Ortodoks Kilisesi” ismiyle tanımlamaya 1847 yılından itibaren başladığı ifade edilmektedir. Ahmet Taşğın, "Süryani Kadim Ortodoks Kilisesinde Yenileşme Çabaları: Deyru'l-Zafaran Manastırında Patriklik Matbaası", Süryaniler ve Süryanilik - IV. Kitap, haz. Ahmet Taşğın, Eyyüp Tanrıverdi, Canan Seyfeli (Ankara: Orient Yayınları, 2005), s. 9.

19 Özcoşar, "Papalığın Müdahalesi ve Süryani Kiliselerinde Bölünme”, s. 287.

20 Sicill-i Nüfûs İdâre-i Umûmiyyesi’nden Diyarbakır Nüfûs Müdüriyeti’ne 8 Mart 1331 (21 Mart 1915) tarihli tahrirat; Başbakanlık Osmanlı Arşivi (BOA), Dâhiliye Nezâreti Sicill-i Nüfus Tahrirat Kalemi (DH.SN.THR.) nr. 60/49 lef 1. Savaştan yaklaşık bir yıl önce Diyarbakır'dan Dâhiliye Nezareti'ne gönderilen nüfus cetvelinde Süryaniler, "Süryani Katolik" ve "Süryani” olarak ayrı ayrı gösterilmişti. BOA, Dâhiliye Nezâreti Muhâberât ve Tensîkat Müdüriyeti (DH.EUM.MTK.) nr. 74/51 lef 1. Savaşs sırasında çıkarılan kararla, bu uygulama artık sonlandırılmış oluyordu. 
Katolik misyonerlere benzer şekilde Protestan misyonerler de Süryanilerle ilgili faaliyetlerde bulunmuşlardı. Fakat Protestanların asıl yoğunlaştıkları millet Ermeniler olmuştu ve Süryaniler arasında Katolikler kadar etkili olamamışlard. Buna rağmen Süryanilerden de Protestan mezhebine geçişler olmuş, özellikle Amerikalı misyonerler Ermeniler kadar olmasa da Süryaniler arasında da taraftar bulmayı başarmışlardı. 1850 yılında Protestan milletinin tanınması ${ }^{21}$ sonrası, 1852 yılında Süryanilerin içindeki bu küçük Protestan nüfus da "Protestan Süryaniler" olarak ayrı bir cemaat oluşturmayı başarmıştı. ${ }^{22}$ Fakat bunlar ayrı bir millet olarak tanınmamışlardı ve ülkedeki bütün Protestanlar gibi İstanbul'daki Protestan Vekili'ne bağlıydılar. ${ }^{23}$ Özellikle Amerikan Board'a (ABCFM) bağlı Protestan misyonerler 1855 yılından itibaren özellikle Mardin üzerinde çalışmalarını yoğunlaştırmışlardı. 1858 yılı ve sonrasında Mardin Anadolu'daki “istasyon”larından birisi olmuştu. Bu durum Süryaniler üzerinde Protestan misyonerlerin etkilerinin açık göstergelerindendi. Süryaniler arasında Prostestanlığa geçişlerin de bu tarihlerden itibaren daha çok arttığı ifade edilmekteydi. ${ }^{24}$

\section{Süryaniler'in Ermeni Milleti'nden Ayrılma Çabaları}

Cemaat içindeki bu dinî problemlerle birlikte Süryani Kadîmlerin Ermeni Patrikhanesi'ne bağlılı̆̆ da onların nazarında büyük bir problem teşkil etmeye devam etmekteydi. İstanbul'da tesis edilen "Patrik Vekilliği” makamının ardından Süryani Kadîm Patrikhanesi, Ermeni Patrikhanesi'ne ve Ermeni milletine bağlı olmaktan kurtulmak için daha yoğun şekilde çalışacaktı. 1863 yılında yürürlüğe giren Ermeni Milleti Nizamnamesi de Süryanilerin durumunda bir değişikliğe

21 Protestan milleti devlet tarafından 1850 yılında tanınmıştı ancak Protestanların ruhani liderine "patrik" unvanı verilmemişti. Protestan dinî lideri "vekil-i millet" olarak "Protestan Vekili” unvanıyla görev yapacaktı. Gülden Sarıyıldız, "Osmanlı Devleti’nde Protestan Ermeni Milleti ve Kilisesinin Tanınması”, Yakın Dönem Türkiye Araştırmaları, İstanbul Üniversitesi Atatürk İlkeleri ve İnkılâp Tarihi Enstitüsü Dergisi, 1/2 (2002), s. 249-267.

22 Aziz Koluman, Ortadoğuida Süryanilik (Dini - Sosyal - Kültürel Hayat) (Ankara: Avrasya Stratejik Araştırmalar Merkezi Yayınları, 2001), s. 23; Sarı, Ermeni Meselesi Işı̆̆̆ında Süryaniler, s. 66-67.

23 Canan Seyfeli, “Osmanlı Devlet Salnamelerinde Süryaniler (1847-1918)”, Süryaniler ve Süryanilik - I. Kitap, haz. Ahmet Taşğın, Eyyüp Tanrıverdi, Canan Seyfeli (Ankara: Orient Yayınları, 2005), s. 122-125.

24 Elçin Macar, "Mardin'deki Amerikalı Protestan Misyonerler ve Kurumları”, Mardin Tebliğleri: Mardin ve Çevresi Toplumsal ve Ekonomik Tarihi Konferansı, ed. Emre Ayvaz, Altuğ Yılmaz (İstanbul: Hrant Dink Vakfı Yayınları, 2013), s. 114. 
neden olmamıştı. Nizamname, "Osmanlı Millet Sistemi" içerisinde Ermeni Patrikhanesi'ne bağlı olan topluluklarla ilgili herhangi bir hüküm içermemekte hatta nizamname hükümleri Ermenileri doğrudan etnik bilinçlenmeye yöneltmekteydi. ${ }^{25}$ Buna rağmen Osmanlı Devleti, nizamname sonrası da Süryanilerin idaresinde değişikliğe gitmemiş, Süryaniler Ermeni Patrikhanesi'nin sorumluluk alanında kalmaya devam etmişlerdi. Süryani Patrikhanesi ise Ermeni Milleti Nizamnamesi yürürlüğe girdikten sonra, Ermenilerden ayrı bir millet olarak tanınmak için taleplerini yoğunlaştırmaya başlamıştı. "Süryani Kadîm”lerin Ermeni milletinden ayrılmaları hususunda en fazla uğraşan patriklerden birisi 1872-1894 yılları arasında "IV. Petrus" adıyla Süryani Patrikliği görevinde bulunan Patrik Petrus olmuştu. ${ }^{26}$ Petrus, patrik seçildikten sonra berâtını almak üzere İstanbul'a gitmiş ve İstanbul'dayken devlet yetkilileriyle Süryanilerin statüsüyle ilgili de temaslarda bulunmuştu. Bazı araştırmacılar Patrik Petrus'un patriklik berâtını almak için yaptığı İstanbul seyahati sırasında, Süryanilerin Ermeni milletinden çıkarılarak ayrı bir millet olarak tanınmalarını yöneticilerin kabul etmelerini sağladığını iddia etmektedirler. Bu görüşe göre Süryaniler 1873 yılından itibaren devlet tarafından, Ermenilerden ayrılarak "Süryani Milleti” olarak tanınmışlardır. ${ }^{27}$ Ancak ne devletin uygulamaları ne de Süryanilerin devam eden talepleri bu görüşü doğrulamaktadır. Hatta Patrik IV. Petrus'a verilen patriklik berâtında da "Süryanilerin Ermeni milletine tâbi” oldukları, önceki dönemlerde olduğu gibi zikredilmektedir. Süryanilerin bu dönemde yine ayrı bir millet olarak tanınmaları ve Süryani Patrikhanesi'nin Ermeni Patrikhanesi'nin otoritesinden çıkarılması talebiyle Bâb-1 Âlî̀ye yeni bir müracaatta bulundukları bilinmekle birlikte, ${ }^{28}$ bu talepler kabul edilmemiştir. Kimi çalışmalarda da önceki dönemlerde yapılan müracaatlardan bir sonuç alınamamakla birlikte Süryani Kilisesi ile yakın ilişkide olan Anglikan Kilisesi’nin desteği ve buna bağlı olarak İngiltere’nin müdahalesiyle 1882 yılında

25 Ermeni Milleti Nizamnâmesi'nin ilân süreci ve içeriği hakkında bkz. Ramazan Erhan Güllü, Ermeni Sorunu ve İstanbul Ermeni Patrikhanesi (1878-1923) (Ankara: Türk Tarih Kurumu Yayınlar1, 2015), s. 39-56.

26 Patrik IV. Petrus'un biyografisi için bkz. Dolabani, Antakya Süryani Kadim (Ortodoks) Patriklerinin Özgeçmişi, s. 180-190. Patrik Petrus'a verilen patriklik berâtı sûreti için bkz. P. Gabriyel Akyüz, Osmanl Devleti’nde Süryani Kilisesi (Mardin: Resim Ofset A. Ş., 2002), s. 26, Belge No: 18.

27 William Taylor bu görüştedir. Eserini de bu kabul üzerine kurgulayarak kaleme almıştır. William Taylor, Narratives of Identity: The Syrian Orthodox Church and the Church of England, 1895-1914 (Newcastle upon Tyne: Cambridge Scholars Publishing, 2013), s. 87-88. 28 Süryaniler tarafından Bâb-1 Âlî̀ye sunulan tezkirenin sûreti için bkz. Akyüz, Osmanlı Devletinde Süryani Kilisesi, s. 14, Belge No: 6. 
Süryanilerin ayrı bir millet olarak tanındıkları ifade edilir. ${ }^{29}$ Bu görüş de doğru değildir. ${ }^{30}$ Osmanlı belgelerinden, Süryanilerin ilerleyen yıllarda da Ermeni milletinden ayrılmak için talepte bulunmaya devam ettikleri görülmektedir. Devletin uygulamaları da Süryanilerin hâlen Ermeni milleti içerisinde kabul edilmeye devam edildiğini göstermektedir. Süryaniler taleplerini yoğunlaştırmakla birlikte o dönemde devlet tarafından "millet" statüsünde tanınmayı başaramamışlardı. Bu durumun 1890'lı yılların ortalarına kadar devam ettiği anlaşılmaktadır. 1893 yılı başlarında Süryaniler yine Ermeni Patrikliği’nden ayrılmak istediklerine dair taleplerini, Mabeyn aracılığıyla doğrudan Sultan II. Abdülhamit'e ileterek dile getirmişlerdi. Kendilerini "eski Babil ahalisinin bakiyyesi" ve "kadîm bir lisâna sahip" bir Hristiyan millet olarak tanımlıyorlar, Ermeni Patrikliği’ne bağlı olmalarının mezhepleri itibariyle de doğru olmadığını belirtiyorlardı. Bulgarların, Bulgar Eksarhlığı'nın tesisi suretiyle Rum Patrikhanesi'nden ayrılmalarını örnek göstererek de ayin usülleri ve dillerinin farklı olduğu Ermenilerden ayrı bir millet olarak tanınmalarını bir kez daha talep ediyorlardı. Ermeni Patrikhanesi'nin zaten kendileri üzerindeki vazifesinin, devletten olan taleplerini Bâb-1 Âlî̀ye iletmekten ibaret - bir anlamda Kapı Kethüdalığı - olduğunu, buna rağmen patrikhanenin Süryanileri Ermeni nüfusu içinde sayarak devletten aldığı vazifeyi de ihlâl ettiğini belirtiyorlard. ${ }^{31}$

$\mathrm{Bu}$ taleple ilgili olarak da yine net bir karar alınmamıştı fakat bu son müracaattan bir yıl sonra yaşanan patrik değişikliği sırasındaki kimi uygulamalardan konuyla ilgili bir değişime gidildiği anlaşılmaktadır. Bu tarihlere kadar Süryani patriklerine verilen berâtlarda "Ermeni milletine tâbi" veya "Ermeni Patrikliği'ne dâhil” gibi ifadeler bulunurken, 1894 yılında Süryani Patriği'nin vefatı sonrası yaşanan patrik değişikliğinde böyle bir ifadeye yer verilmemişti. Aynı durum

29 Benjamin Trigona-Harany, The Ottoman Süryânî from 1908 to 1914 (Piscataway-NJ: Gorgias Press, 2009), s. 100; Mutay Öztemiz, II. Abdülhamitten Günümüze Süryaniler (İstanbul: Ayrıntı Yayınları, 2012), s. 38.

30 Khalid S. Dinno, bazı batılı araştırmacıların çalışmalarına atıf yaparak bu tarihin Süryanilerin bağımsız bir millet olarak kabul edildiği tarih olarak görüldüğünü ifade eder ve o da bunun yanlışlı̆̆ını vurgular. Sonraki yıllarda konuyla ilgili devam eden taleplere işaret ederek kendisi de 1882 'de Süryanilerin bağımsız bir millet olarak kabul edilmediklerinin açık olduğunu belirtir. Khalid S. Dinno, "The Syrian Orthodox Christians in the Late Ottoman and Post-Ottoman Periods: Crisis and Revival" (doktora tezi), Department of Near and Middle Eastern Civilizations, University of Toronto, 2015, s. 61-63.

31 Süryanilerin talepleri hakkında Mabeyn Baş Kitâbet'in Sultan II. Abdülhamit'e 22 Şubat 1308 (6 Mart 1893) tarihli arz tezkîresi; BOA, Yıldız Esas Evrâkı (Y.EE.) nr. 38/71. 
bundan sonra göreve gelecek olan Süryani patriklerinin berâtlarında da görülmeye devam edilecekti. Devlet Salnameleri'ne dayanılarak yapılan çalışmalardan da anlaşıldığına göre, patrikliklerin berâtları ile birlikte devletin diğer uygulamaları da Süryanilerin bu yıllardan itibaren Ermeni milletine bağlı olmaları durumunun resmî yazışmalardan çıkarıldığını doğrulamaktadır. ${ }^{32}$

1894 yılında Patrik IV. Petrus'un vefatı üzerine 1895 'te patrikliğe seçilen Abdül-Mesih Efendi'ye verilen berâtta Süryanilerin Ermeni milletine tâbi olmaları hakkında herhangi bir ifade yer almamakta, "Süryani Kadîm Cemaatinin Patrikliği” ne Abdül-Mesih Efendi'nin atandığı beyân edilmekteydi. ${ }^{33}$ Bununla birlikte patriğin berâtında yapılan bu değişiklik de Süryanilerin, Ermeni milletine dâhil olmaktan çıkarıldığını net olarak göstermediği gibi, resmî olarak ayrı bir millet olarak tanındıkları anlamına da gelmemekteydi. Abdül-Mesih'in berâtında görüldüğü üzere Süryanilerden - eskiden olduğu gibi - "millet" olarak değil "cemaat" olarak bahsedilmekteydi. Fakat Ermenilere bağlılıklarından bahsedilmemesi önemli bir ayrıntı olarak görülmelidir. Dolayısıyla elimizde bu hususta açık bir vesika bulunmamakla birlikte devam eden süreçteki uygulamalardan anlaşıldığı kadarıyla Süryaniler, 1894-1895 yıllarından itibaren fiilî olarak Ermeni Patrikliği'ne bağlı olmaktan çıkmışlardı. Süryani Kadim Patrikhanesi artık Ermeni Patrikhanesi'ni aracı olarak kullanmadan Bâb-1 Âlî ile ilişkilerini doğrudan yürütebilecektir. Devlet resmen ifade etmese de bu tarz bir uygulama, aslında de facto olarak Süryanilerin ayrı bir millet olarak kabul edildikleri anlamına gelmekteydi. Bu durum devletin sonraki yıllardaki uygulamalarıyla daha da netleşecekti.

Süryaniler ve Ermeniler arasındaki ayrışmanın bu şekilde belirgin hâle gelmesinde, 1894 ile 1896 yılları arasında özellikle Doğu Anadolu'da yaşanan Müslüman - Hristiyan çatışmaları da etkili olmuştu. Ermeni komitelerince organize edilen ancak Müslüman ahalinin Hristiyanlara yönelik sert tepkisiyle ağır çatışmalara dönüşen olaylar sırasında Ermeniler ve Süryaniler arasındaki ilişkiler oldukça yakınken, devam eden süreç aksi gelişmelere sebebiyet vermişti. Ermeni komiteleri, isyanlar ve sonrasında yaşanacak Müslüman - Hristiyan çatışmaları ile

32 Farklı çalışmaların aksine Süryanilerin 1890’lı yıllarda Ermeni Patrikhanesi’ne bağlı olmaktan çıtıkları hususuna ilk defa vurgu yapan Canan Seyfeli'dir. Seyfeli, "Osmanlı Devlet Salnamelerinde Süryaniler", s. 72-75; Canan Seyfeli, "Millet Sistemi ve Osmanlı Devlet Salnamelerinde Süryani Kadim Patrikliği (1847-1918)”, Sosyal Bilimler Araştırma Dergisi (SBArD), 15/29 (Bahar, 2017/1), s. 17-45.

33 Patrik Abdül-Mesih Efendi'ye verilen berât sûreti için bkz. Akyüz, Osmanlı Devleti'nde Süryani Kilisesi, s. 11, Belge No: 3. 
hem Avrupalı devletlerin Osmanlı Devleti'ne müdahalelerini hem de bölgedeki Hristiyan unsurların daha yakın hâle gelerek ortak hareket etmelerini sağlamayı hedeflemişlerdi. Bölgedeki Kürt aşiretlerinin Hristiyanlara yönelik saldırıları da yerli Hristiyanlar arasında bu tür bir dayanışmaya zemin hazırlamışı. Süryanilerin bölgedeki Müslüman unsurlarla ilişkileri genel anlamda zaten gergin bir geçmişe sahipti. Özellikle Kürt aşiretleri ile Süryaniler arasında - aşiretlerle Ermeniler arasında da olduğu gibi - çatışmalı bir ilişki söz konusuydu. 19. yüzyıl başlarından itibaren Rusya’nın bölgeye doğrudan müdahalesiyle Müslümanlar ve Hristiyanlar arası ilişkiler daha da sertleşecekti. II. Abdülhamit tarafından bölgede asayişi sağlayabilmek adına kurulan Hamidiye Alayları da düzeni sağlamak bir yana zamanla düzensizlik ve asayişsizliğin temel sebeplerinden birisi haline gelecekti. ${ }^{34}$

Süryani Patrikhanesi'nde 1895 yılı Temmuz ayında yaşanan patrik değişikliğinden birkaç ay sonra Ekim ve Kasım aylarında Anadolu'nun birçok yerinde olduğu gibi Diyarbakır ve Bitlis vilayetleriyle civarında da Ermeni komitelerince başlatılan ve ardından Müslüman ahalinin Ermenilere tepkisi ve Kürt aşiretlerinin saldırıları ile yayılan sert bir Müslüman - Hristiyan çatışması yaşanmışıtı. Olay sadece Ermeniler ve Müslümanlar arasında kalmamış Süryaniler de olaylara dâhil olmuşlar ve genel olarak zarar görmüşlerdi. Süryani Patriği Abdül-Mesih Efendi yaşanan kargaşa sırasında Diyarbakır'a gelmiş, hem ahali ile hem de yerel yetkililerle sürekli temas haline bulunarak Süryanilerin güvenliğini sağlayabilmek için uğraşmıştı. ${ }^{35}$ Kimi Hristiyan din adamları ve ahaliye göre "Müslümanlar, bölgedeki bütün Hristiyanları yok etmek için harekete geçmişlerdi” ${ }^{36}$ ve olayların baş sorumlusu Diyarbakır Valisi Enis Paşa idi. Bölgede görevli Avrupalı sefir ve konsoloslar da benzer düşüncedeydiler ve sürekli Enis Paşa’yı suçlayan beyanlarda bulunmaktaydılar. İstanbul'a da sürekli Paşa hakkındaki şikâyetlerini iletmekteydiler ve yaşanan bu durum, olaylardan yaklaşık bir yıl sonra Enis Paşa’nın

34 İbrahim Özcoşar, “Süryani-Müslüman İlişkileri”, Makalelerle Mardin IV-Önemli Simalar - Dini Topluluklar, haz. İbrahim Özcoşar (İstanbul: Mardin Tarihi İhtisas Kütüphanesi Yayını, 2007), s. 197-217. 1894-1896 çatışmaları ve olaylar sırasında/sonrasında Protestan misyonerlerin tavır ve faaliyetleri hakkında bkz. Hans-Lukas Kieser, Iskalanmış Barış: Doğu Vilayetleri'nde Misyonerlik, Etnik Kimlik ve Devlet 1839-1938, çev. Atilla Dirim (İstanbul: İletişim Yayınları, 2010), s. 210-260.

35 Mehmet Şimşek, Süryaniler ve Diyarbakır (İstanbul: Chiviyazılar Yayınevi, 2003), s. 164.

36 Kimi Süryanilere göre "Müslümanlar sadece devlete isyan eden Ermenileri öldürdüklerini söylemelerine rağmen aslında tüm Hristiyanları yok etmek niyetindeydiler." Dolayısıyla Süryaniler de yaşananların Hristiyanlara yönelik bir katliam olduğunu ve kendilerinin de bu katliamların mağduru olduklarını ifade etmekteydiler. Taylor, Narratives of Identity, s. 107. 
görevinden azliyle neticelenecekti. ${ }^{37}$ Ayrıca Enis Paşa'dan şikâyetçi olanlar sadece Ermeniler veya diğer gayrimüslim topluluklar değildi. Müslümanlar arasında da Paşa’ya yönelik eleştiriler ve bazı uygulamalarından memnuniyetsizlikler bulunduğu bilinmekteydi. ${ }^{38}$

Yaşanan bu olaylar, özellikle hadiselerin başladığı sıralarda Ermenilerle Süryaniler arasında genel anlamda bir yakınlığa sebebiyet vermişti. İdari durumdaki kargaşa ve yetersizlikler içinde çıkan olaylarla Ermeni komiteciler birçok yerde Müslümanlarla Hristiyanları karşı karşıya getirmeyi başarmalarına ve bölgede Osmanlı Devleti'ni hem idari hem askeri anlamda oldukça zor şartlarda bırakmalarına rağmen Avrupalı devletlerin Osmanlı Devleti'ne askerî anlamda müdahalesi sağlanamadığı gibi, olaylar sonlandıktan ve kargaşalar durulduktan sonra Hristiyan unsurlar arasındaki birliktelik de çatışmalar başladığı sırada olduğu gibi yakın şekilde devam etmemişti. Hatta olayların sonlandırıldığı günlerde, hadiseler hâlâ canlılığını korurken, Bitlis'ten bazı Süryaniler İstanbul'a çektikleri telgraflarda olayların sorumlusu olarak Ermeni komitecilerini göstermişler ve bölgedeki Süryanilerin de yaşananlardan sorumlu olduklarının düşünülmemesi gerektiğini belirtmişlerdi. ${ }^{39}$ Bir süre sonra İstanbul'daki Süryani Patrik Vekili de Sadaret'e bir istida sunarak Bitlis, Diyarbakır ve Mamuret-ül-aziz vilayetleriyle Urfa Sancağı'nda yaşayan Süryanilerin, Ermeni komitecileri yüzünden felaket ve musibetlere maruz kaldıklarını ifade etmiş, yaşanan olaylarda Süryanilerin dahli olmadığını dile getirmişti. Patrik Vekili ayrıca, Ermenilerin eskiden beri sürdürmeye çalıştıkları ayrılıkçı hareketlere Süryaniler destek vermedikleri ve Ermeni nüfûzuna girmeyi kabul etmedikleri için Ermenilerin düşmanlık ve baskılarına maruz kaldıklarını söylüyordu. Bu baskılar; Ermeniler tarafından Süryani kilise ve manastırlarına el konulması, kadîm eserlerinin mahvedilmesi, din adamlarının hakaret ve darblara maruz kalması, Süryani

37 Süryanilerin Enis Paşa hakkındaki şikâyetleri ve Diyarbakır Vilayeti’ndeki çatışmalar ile ilgili olarak bkz. Dolabani, Antakya Süryani Kadim (Ortodoks) Patriklerinin Özgeçmişi, s. 191-192; Taylor, Narratives of Identity, s. 94-108. Diyarbakır'da yaşanan 1895 yılı olayları ve Enis Paşa hakkındaki tartışmalar için ayrıca bkz. Ramazan Erhan Güllü, "1895-1896 Ermeni İsyanlarında Batılı Devletlerin Osmanlı Devleti’ne Yönelik Tutumlarına Bir Örnek: Enis Paşa'nın Diyarbakır ve Halep Valiliklerine Karşı Tepkiler”, Ermeni Ayaklanmalar (1894-1909) Sempozyumu (23 Ocak 2014, Ankara) Bildirileri (Ankara: Türk Tarih Kurumu Yayınları, 2015), s. 180-188.

38 Abdulgani Fahri Bulduk, Diyarbakır Valileri, yay. haz. Eyyüp Tanrıverdi, Ahmet Taşğın (İstanbul: Medrese Yayınları, 2007), s. 184.

39 Bitlis Süryanilerinden bazılarının imzalarıyla Sadaret'e çektikleri 15 Teşrîn-i Sânî 1311 (27 Kasım 1895) ve 22 Teşrîn-i Sânî 1311 (4 Aralık 1895) tarihli telgrafları; BOA, Tahrîrât-ı Hâriciye Odası (HR.TH.) nr. 166/20 lef 1-3. 
ahalinin kendi ayinlerinden men edilmesi, mezarlıklara dahi müdahale edilerek ölülerini kendi mezarlıklarına gömmelerine engel olunması şeklindeydi. Son olaylar sırasında da Ermeni ayrılıkçıları kendilerini desteklemeyen Süryanilere saldırmışlar, mal ve mülklerine zarar vermişlerdi. Süryanilere asıl zarar verenlerin Kürt aşiretleri olduğunu, yağma ve katl işlerini en çok Kürtlerin yaptığını da vurgulayan Patrik Vekili, buna karşılık komiteci Ermenilerin yaptıklarının da görmezden gelinmemesi gerektiğini belirtiyordu. Ermeniler, Avrupa'dan aldıkları paralarla ve Avrupalıların desteği ile hareket ederken, Süryanilerin Osmanlı Devleti dışında hiçbir devletten destek alan bir topluluk olmadıklarını ve Osmanlı Devleti'ne sâdık ve tâbi olmaktan hiçbir zaman uzaklaşmadıklarını vurgulayan Patrik Vekili, Sadaret'ten Ermenilerle Süryanilerin aynı şekilde değerlendirilmemesini ve Süryanilere destek olunmasını istiyordu. ${ }^{40}$

Patrik Vekili’nin istidasından bir hafta önce de Süryani Patriği Abdül-Mesih Efendi, bazı Süryani din adamları ve ahalinin önde gelenleri ile birlikte doğrudan Sultan II. Abdülhamit'e hitâben Mabeyn'e yolladığ 1 bir istidada benzer ifadelerde bulunmuştu. Bölgede yaşanan karışıklıklardan birkaç ay önce patrik seçilmiş olan Süryani Patriği Abdül-Mesih Efendi ${ }^{41}$ daha önce de ifade ettiğimiz gibi yaşanan karışıklıklar sırasında Süryanilerin güvenliğini sağlayabilmek için yerel yöneticilerle de temasta bulunarak yoğun bir şekilde çalışmıştı. Bazı din adamları ve cemaat muteberânının da imzalarıyla Sultan’a yolladığı istidada Patrik Efendi, olayların öncesinde komitecilerin faaliyetlerine dâir hiçbir bilgiye sahip olmadıklarını, çatışmalar başladıktan sonra ise Ermeni komitecilerinin Süryanileri de kendilerine destek olmaları hususunda zorladıklarını öğrendiklerini belirtiyordu. Gerek Ermenileri destekleyen gerek komitelerin propagandalarına kapılarak komitecilerle birlikte hareket eden Süryanileri engellemek için uğraştıklarını ve onlara nasihatlerde bulunduklarını ifade eden Abdül-Mesih Efendi, "dedelerimizden bize en kıymetli miras olan sadakatimizi korumaktan vazgeçmedik" diyordu. Ermenilere destek verenler ise Süryanilerin küçük bir kısmıydı. Bu yüzden Patrik de Ermenilerle Süryanilerin aynı şekilde değerlendirilmemesi istirhâmında bulunuyordu..$^{42}$ Olayın

40 İstanbul Süryani Patrik Vekâleti'nden Sadaret'e 15 Kanûn-1 Evvel 1311 (27 Aralık 1895) tarihli istida; BOA, Sadâret Mektûbî Kalemi Mühimme Odası (A.MKT.MHM.) nr. 609/36 lef 2 .

41 Süryani Kadîm Milleti Patrikliği'ne Suriye Matranı Abdül-Mesih Efendi'nin seçildiğine dâir Sadaret'ten Adliye ve Mezâhib Nezareti'ne 11 Temmuz 1311 (23 Temmuz 1895) tarihli tezkire; BOA, Bâb-ı Âlî Evrak Odası (BEO.) nr. 660/49438.

42 Süryani Patriği Abdül-Mesih Efendi ile bazı Süryani din adamı ve muteberânı tarafından Mabeyn'e yollanan 7 Kanûn-1 Evvel 1311 (19 Aralık 1895) tarihli istida; BOA, Yıldız 
üzerinden yaklaşık altı ay geçtikten sonra, Diyarbakır'dan Sadaret'e yolladığı başka bir tahriratında da Abdül-Mesih Efendi, olaylardan yine Ermenileri sorumlu tutmuş hatta olayların sorumlusu olduğu gerekçesiyle sürekli eleştirilen Diyarbakır Valisi Enis Paşa'yı savunmuştu. Patriğe göre Enis Paşa’ya yönelik eleştirilerin çoğu haksızdı ve istidasında "Ermeni fesedesi" tarafından çıkarılan olaylar sırasında Vali Enis Paşa'nın her kesimden ahalinin huzurunu temin için özenle çalıştığını ve onun çalışmaları sayesinde vilayette huzurun tesis edilebildiğini anlatmıştı. Patrik, Sadaret'ten ayrıca fesadçılara karşı çalışmalarıyla bölgedeki Müslim ve gayrimüslim ahalinin huzurunu sağlayan Paşa’nın "rütbesinin terfî iyle taltîfini” talep ediyordu. Sonraları, kimi gayrimüslimler tarafından patriğin bu tahriratı Vali'nin zorlamasıyla yollamak zorunda kaldığı iddia edilmişti. (Benzer olarak Sultan'a ve Sadaret'e yollanan diğer arîza ve istidalarında kasten ve zorlamayla yazdırıldığ düşünülmekteydi.) O sırada yaşananlar düşünüldüğünde, patriğin tahriratındaki ifadeleri gerçekten Vali'nin zorlamasıyla kaleme almak zorunda kaldığı veya bu şekilde bir tahrirat vesilesiyle bölgedeki Süryanileri korumak kastıyla yönetimle yakın ilişkiler kurmaya çalıştığı söylenebilir. Bunların tamamen doğru olduğu düşünülse dahi patriğin "Ermeni fesedesi”ni suçlayarak kendilerinin Ermenilerden ayrı olduklarını özellikle vurguladığı da açıktır ve Süryanilerin idaresindeki dönüşümlerin anlaşılması açısından bu husus oldukça önemlidir. ${ }^{43}$ Benzer ifadeler aynı dönemde Süryani cemaatinin farklı kesimlerince de dile getirilmiştir. İstanbul'a yollanan bu tür yazıların tümünde, "Ermeni fesâdcıları" ile alakalarının olmadığı

Perâkende Evrakı Adliye ve Mezâhib Nezâreti Maruzâtı (Y.PRK.AZN.) nr. 15/1 lef 1.

43 "Geçenlerde bazı Ermeni fesedesinin Anadolu Vilâyât-1 Şâhânesi'nin her tarafinda ika'ına sebeb oldukları iğtişâşât Diyarbakır’a kadar sirâyet etmiş ise de sâye-i kudret-vâye-i hazret-i pâd-şâhîde cümleden ziyade bezl-i mesâi ve gece gündüz hâvâb-ü-rahâtı terk ederek metbû-i müfahham ve muazzamamız olan pâd-şâh-1 tebea perver efendimizin meyâmin-i irtika-yı hazret-i tâc-dârîlerine muvâfik sûretde hareket eylediğini müşâhade eylediğim Diyarbakır Vilâyet-i Âliyyesi Vâlisi âtufetli Enis Paşa hazretleri umûmun emr-i istirâhat ve huzurları uğrunda ittihâz buyurdukları tedâbir-i meşkûre eseriyle cümleye mûcib-i te’mîn olduğu ... zat-1 akdes-i hazret-i mülükâneye muvâfik sûretde hareket eden bendegân(ın) [...] beyne'l-akran mûcib-i fahr ü mübâhat olmak üzere rütbesinin terfî̀iyle emsâli misüllü taltîf buyrulması [...]" Süryani Patriği Abdül-Mesih Efendi'nin Diyarbakır'dan Sadaret'e yolladığı 9 Mayıs 1312 (21 Mayıs 1896) tarihli tahriratı; BOA, Sadâret Evrak Kalemi (A.VRK.) nr. 140/19. Patriğin tahrirâtı ve o dönemde yaşananlar hakkında ayrıca bkz. Ramazan Erhan Güllü, “1895-1896 Ermeni İsyanlarının Osmanlı Vilayet İdaresine Etkileri: Halep Örneği”, OTAM (Ankara Üniversitesi Osmanlı Tarihi Araștırma ve Uygulama Merkezi Dergisi), 32 (Güz 2012), 2013, s. 22. 
ifade ediliyorsa da esas amacın Süryanilerin ayrı bir millet olduklarını vurgulamak olduğu anlaşılmaktadır. ${ }^{44}$

Ayrıca bu dönemden itibaren Süryani Patrikhanesi, Avrupalı devletler ile yakın ilişkilerde bulunmaya başlamıştı. Fakat patrikhanenin batıda yakınlık kurduğu esas güç İngiltere idi. Diyarbakır ve bölgesindeki Avrupalı sefir ve konsoloslar aracıllı̆ıgla batılı devletlerle zaten temas halinde olan Patrikhane, kiliseler arası ilişkilerde de batıya yakın bir anlayış benimsemeye başlamış, bu bağlamda da İngiliz Anglikan Kilisesi ile olan ilişkilerini sıkılaştırmıştı. Özellikle Fransa’nın Katolikler lehine süregelen müdahaleleri dolayısıyla Süryani Patrikliği, İngiltere ile yakın olmayı Fransa'ya karşı kendini koruma gibi algılamaktaydı. Son süreçte Fransa bölgedeki Katolik misyonerlik faaliyetlerini daha da yoğunlaştırmıştı. Süryani Patrikhanesi, Katoliklerin faaliyetlerine karşı otoritesini korumak için devletten de yardım istemeye devam etmekteydi. Ancak bölgede otoritesini hissettirmekte zorlanan Osmanlı Devleti bu hususta patrikhaneyi eskiden olduğu gibi koruyamamaktaydı. Ayrıca bölgede yaşanan son çatışmalar sırasında Fransa’nın Katolik Ermeniler ve Süryaniler lehine müdahale ve desteklerinin görülmesi, Süryani Patrikhanesi'ni bir yandan daha fazla Ortodoks'un Katolikliğe geçişine engel olmak diğer yandan siyasi açıdan da güçlü bir Avrupa devletinin daha fazla desteğine sahip olmak gibi düşüncelerle Anglikan Kilisesi ile ilişkilerini güçlendirmeye yöneltmişti. Fransa'nın desteğiyle güçlerini artırma potansiyeline sahip olan Katolik Süryaniler, Süryani Kadîm Patrikliği için Ermeni Patrikhanesi'ne tâbi olmak kadar hatta ondan daha tehlikeli bir durumu ifade etmekteydi. ${ }^{45}$

\section{Süryani Milleti Nizamnamesinin Hazırlanışı}

1894-1896 yıllarından itibaren Ermenilerden ayrı olarak şekillenmeye başlayan Süryanilerin idaresine paralel olarak Süryani Patrikhanesi, Osmanlı Devleti ile çatışmadan uzak tavrını sürdürmüştü. Fransa’nın Katolikler lehine müdahalelerine karşı kendisi de İngiltere ile yakın ilişkilerde bulunan Süryani Kadîm

44 Özcoşar, "Osmanlida Hristiyan Cemaatler Arası İlişkiler", s. 11-13. William Taylor da, bazı Süryani din adamları ve liderlerinin bu dönemdeki tavırlarını, Süryanilerin Ermenilerden ayrı bir millet haline geldiklerinin ve bunun Osmanlı Devleti'nce de kabul edildiğinin kesin göstergeleri olarak anlatır. Taylor, Narratives of Identity, s. 155-164.

45 Dinno, "The Syrian Orthodox Christians", s. 141-154; Taylor, Narratives of Identity, s. 94-98. Devam eden süreçte Süryani Patrikhanesi ile Anglikan Kilisesi arasındaki dinî münâsebetler hakkında bkz. Dinno, "The Syrian Orthodox Christians", s. 154-163; Taylor, Narratives of Identity, s. 109-147. 
Patrikliği, Osmanlı Devleti'nin mevcut idaresi ile yaşanabilecek problemlerden de uzak durma eğilimindeydi. 1894-1896 yıllarında yaşanan yaygın çatışmalardan sonra Doğu Anadolu bölgesinde benzer şiddet olaylarına rastlanmamıştı. II. Abdülhamit döneminin sonuna kadar Süryaniler, resmî olarak Ermeni milletine tâbi kabul edilmemekle birlikte ayrı bir millet olarak da tanınmayarak idari yapılarını sürdürmüşlerdi. İstanbul'daki patrik vekilliği artık doğrudan devletle temasta bulunabiliyordu ancak bunu statüsü belirsiz olan "Süryani cemââti" adına yapıyordu. II. Abdülhamit, gayrimüslimlerin idaresindeki klasik tavrını bu hususta da sürdürerek, patrikhane idaresinin hükümetle çatışmadan uzak durması karşılığında Süryanilerin idaresini Ermeni Patrikhanesi aracıllğıyla yürütme politikasına dönmemişti. Dolayısıyla Süryaniler "de facto" olarak ayrı bir millet statüsü elde etmiş oluyorlardı. Bununla birlikte Süryaniler arasında da II. Abdülhamit'e muhalif ve Meşrutiyet'e giden süreci destekleyen gruplar bulunmaktaydı. 1908 yılında Osmanlı Devleti'nde anayasanın yeniden yürürlüğe girmesiyle oluşan Meşruti yönetimle birlikte de Süryanilerin idaresi hakkında net bir karar alınmamıştı. Süryani milleti hâlen "de facto" olarak millet statüsünde idare edilmekte, Ermeni Patrikhanesi Süryanilerle ilgili işlerde muhatap kabul edilmemekte, Süryanileri ilgilendiren işlerle doğrudan Süryani Patrikhanesi ve ona bağlı yetkililer ilgilenmekteydi. Buna rağmen bu fiilî durumu resmileştiren herhangi bir karar veya hukuki metin bulunmamaktaydı. Bu yüzden Meşrutiyet sonrası Süryanilerin kendileri için de bir nizamname hazırlanması yönündeki beklentileri daha da artmıştı. Süryani basını da bu konuyu sık sık gündeme getirmekteydi. Ayrıca Süryani kamuoyu nizamname dışında da Meşrutiyet sonrası yeni yönetimden birçok beklentiye sahipti. İlerleyen süreçte Meşrutiyet idaresinden beklediklerinin tam olarak karşılanmadığına dair eleştiriler görülmeye başlansa da Süryani basını büyük oranda "Osmanlılık" vurgusunu sürdüren yayınlar yapmaya devam etmişti. ${ }^{46}$ Bununla beraber Süryani milletinin haklarının korunması da basının gündemde tuttuğu hususlardandı ve bu konuda da sık sık Süryani Patrikhanesi’ne yönelik eleştirilerde bulunulmaktaydı. Süryani basını genel anlamda, patrikhanenin Süryani milletinin ihtiyaçlarını karşılamakta yetersiz kaldığı görüşündeydi. Ruhbanların büyük oranda cahil, yetersiz ve milletin ihtiyaçlarından habersiz olduğu, çocukların eğitimi için gerekli sayıda okul ve öğretmen bulunmadığı ifade edilmekteydi. Bu sorunu çözmek için bazı Süryani cemiyetleri de kurulmuştu fakat onlar da beklenen seviyede çalışmalar yapamamışlardı. Cemiyetler de çalışma yapmak istedikleri konularda patrikhanenin çeşitli müdahalelerinden şikâyetçiydiler. Aslında yaşanan bu tartışmalar diğer

46 Trigona-Harany, The Ottoman Süryânî, s. 113-151. 
gayrimüslim milletlerde de görüldüğ̈ gibi Süryani milletinde de var olan ruhani - sivil çatışmalarının yansımalarıydı. ${ }^{47}$

Patrikhaneye yönelik eleştirileri önlemenin ve Süryani kamuoyunun eleştirileri çerçevesinde milletin beklentilerini karşılamanın en önemli şartı, diğer gayrimüslim milletlerde olduğu gibi Süryaniler için de bir nizamname hazırlayarak patrikhanenin özellikle sivil/idari anlamda yetki ve sorumluluklarının tam olarak belirlenmesiydi. Bu çerçevede 1913 yılında, Süryani milleti için bir nizamname hazırlanması için çalışmalar hızlandırılmıştı. Dönemin Süryani Patriği Abdullah Efendi, 3 Mayıs 1913 tarihinde Adliye ve Mezahib Nezareti'ne sunduğu bir takrirde, diğer gayrimüslim milletlerde olduğu şekliyle bir nizamnameye sahip olmadıklarından dolayı millet işlerinin örf ve kadîm adetleri üzere yapılmakta olduğunu, bu durumun ise zamanın şartlarına uygun olmadığını ifade etmişti. Bu yüzden Süryanilerin de bir nizamnameye sahip olabilmeleri için altı din adamı ile altı sivil yetkiliden oluşan bir heyet (meclis-i muhtelit) seçildiğini belirten patrik, bu heyet tarafından kendileri için bir nizamname hazırlanarak hükümetin onayına sunulmasına müsaade edilmesini istiyordu. ${ }^{48}$ Adliye ve Mezahib Nezâreti, patriğin takririni üzerinden birkaç ay geçtikten sonra Sadaret'e iletirken, Islahat Fermanı sonrası gayrimüslim milletlerin kendi dinî merkezlerinde oluşturulacak heyetler vasıtasıyla nizamnamelerini hazırlamalarının öngörüldüğünü, buna bağlı olarak da İstanbul ve Kudüs Rum Patrikhaneleri ile Ermeni Patrikhanesi, Hahamhane ve Protestan nizamnamelerinin hazırlanmış olduğunu hatırlatmıştı. ${ }^{49}$ Nezaretin görüşünü Divân-1 Hümâyun da doğrulayarak patrikhanenin talebinin yerinde olduğunu onaylamış, Islahat Fermanı sonrası yayımlanan diğer gayrimüslim millet nizamnameleri gibi Süryaniler için de belirlenen heyet tarafından bir nizamname hazırlanmasının uygun olduğunu belirtmişti. ${ }^{50}$ Aynı görüş Meclis-i Vükelâ tarafından da tekrarlanmış ve patrikhanenin oluşturduğu on iki üyeli Meclis-i Muhtelit'in Süryani milleti için bir nizamname hazırlaması talebi uygun bulunarak onaylanmıştı. ${ }^{51}$

47 Trigona-Harany, The Ottoman Süryânî, s. 153-173.

48 Süryani Kadîm Patriği Abdullah Efendi'den Adliye ve Mezâhib Nezâreti'ne 20 Nisan 1329

(3 Mayıs 1913) tarihli takrir; BOA, BEO. nr. 4230/317250 lef 3. Patrikhane tarafindan nizamnameyi hazırlamakla görevlendirilen meclis-i muhtelitin sivil ve ruhani üyelerinin isimlerini hâvî pusula; Aynı Vesika, lef 4.

49 Adliye ve Mezâhib Nezâreti’nden Sadaret'e 7 Eylül 1329 (20 Eylül 1913) tarihli tezkire; Aynı Vesika, lef 2.

5021 Eylül 1329 (4 Ekim 1913) tarihli Divân-1 Hümâyun müzekkeresi; Aynı Vesika, lef 5.

5127 Teşrîn-i Evvel 1329 (9 Kasım 1913) tarihli Meclis-i Vükelâ Mazbatası; BOA, Meclis-i Vükelâ Mazbataları (MV.) nr. 182/25. Nizamname ile ilgili yazışmalar ve nizamnamenin 
Karar patrikhaneye de iletilmiş, böylece 1913 yılı Kasım ayı itibariyle nizamname için çalışmalar resmen başlatılmıştı. Muhtelit Meclis'in yaklaşık üç ay süren çalışması ile nizamname metni ortaya çıkarılmıştı. Bunun ardından da nizamnamenin resmî onayı için yeniden hükümetle temasa geçilmişti. Nizamname metni üç nüsha olarak hazırlanmış, birisi Adliye ve Mezahib Nezareti'ne teslim edilmek üzere mahallî hükümete verilmiş, diğer iki nüshanın da biri patriğe diğeri de İstanbul'daki patrik vekiline takdim edilmişti. 1914 yılı Mart ayı sonlarında nüshaların tesliminin tamamlandığı tahmin edilmektedir. 8 Şubat 1914 tarihinde Osmanlı Devleti ile Rusya arasında imzalanan "Yeniköy Antlaşması" ile Doğu Anadolu'ya iki Avrupalı müfettiş görevlendirilerek "Ermeni Islahatı" için çalışmaların başlatılmasının $\mathrm{da}^{52}$ süreci etkileyen unsurlardan olduğu düşünülebilir. Gayrimüslim topluluklarla ilgili Tanzimat sürecinde olduğu gibi yeni "reform”ların gündemde olduğu bir dönemde, Süryani Milleti Nizamnamesi'nin de kısa sürede uygulamaya konulmasının beklenmesi doğaldı. Nizamname toplam 64 maddeden oluşmaktaydı ve içeriği Islahat Fermanı sonrası yürürlüğe giren diğer gayrimüslim millet nizamnamelerinden farklı değildi. Ağırlıklı olarak da Ermeni Milleti Nizamnamesi esas alınarak hazırlanmıştı. Nizamnameyle ilgili çalışmalar prosedüre uygun bir şekilde yürütülmüş ve nizamname, onay için Süryani yetkililer tarafindan Adliye ve Mezâhib Nezareti'ne iletilmiş olmakla birlikte, nizamnamenin devlet tarafından resmen onaylanarak yürürlüğe konulmadığı anlaşılmaktadır. Zira nizamname metni Düstur'da resmen yayımlanmadığı gibi uygulamaya dâir daha başka bir resmî evrak da bulunmamaktadır. Süryanilerce yayımlanan Hikmet Mecmuasinın 24 Haziran 1914 tarihli ve 21 numaralı nüshasında, "Patriğimiz patrikhane nizamnamesini tasdik ve asitanede Adliye ve Mezahib Nezareti'ne takdim ve yüce Nezaret maddelerini tetkik için Devletin Şûra meclisine havale etmiştir" şeklinde bir haber yer almıştır. ${ }^{53}$ Dolayısıyla Mart ayında nezarete iletilen nizamname metni ile ilgili çalışmaların Haziran ayında hâlen devam ettiği görülmektedir. Temmuz ayında başlayan Dünya Savaşı dolayısıyla Osmanlı Devleti'nin savaşla ilgili gelişmelere odaklanması muhtemelen nizamnameyle ilgili çalışmaların askıya alınmasına neden olmuş, birkaç ay sonra Osmanlı Devleti’nin

hazırlanış sürecinde yapılan çalışmalar hakkında ayrıca bkz. Haşim Erdoğan, "20. Yüzyılın İlk Yarısında Türkiye’deki Süryaniler” (doktora tezi), Erciyes Üniversitesi Sosyal Bilimler Enstitüsü, 2013, s. 23-29.

52 Yeniköy Antlaşması ve Ermeni ıslahatına dâir çalışmalar için bkz. Güllü, "Ermeni Sorunu”, s. $443-451$.

53 Mustafa Emil Elöve, “Türkiye'de Din İmtiyazları: Bölüm II - Ermeniler”, Ankara Üniversitesi Hukuk Fakültesi Dergisi, XI/1-2 1954, s. 247. 
de savaşa dâhil olmasıyla nizamname hakkındaki çalışmalar tamamen durdurulmuştur. Savaşla birlikte, "Ermeni Islahatı" hakkındaki "Yeniköy Antlaşması" da iptal edilerek, ıslahata dâir başlatılan uygulamalar sonlandırılmıştı. Ermeni ıslahat projesi ile ilgili çalışmaların durdurulduğu, müfettişlik teşkilâtının lağvedildiği ve diğer gayrimüslim millet nizamnamelerinin de uygulamadan kaldırıldığı bir ortamda Süryani Milleti Nizamnamesi'nin onaylanması gibi bir durum zaten söz konusu olamazd $1 .{ }^{54}$

Devlet tarafından resmen onaylanmamış olsa da nizamnamenin içeriği Süryani milletinin idaresi ile ilgili getirilmek istenen yapının anlaşılmasını sağlamaktadır. Ayrıca yine devlet tarafından onaylanmasa dahi Birinci Dünya Savaşı ve sonrasında Süryani Patrikhanesi'nin kendi iç işleyişinde nizamname hükümlerini uyguladığı anlaşılmaktadır. Hatta patrikhane 1932 yılında Türkiye'den taşınmadan önce, Patrikhane Muhtelit Meclisi tarafindan nizamnamenin ilk iki maddesi değiştirilmişti. ${ }^{55} \mathrm{Bu}$ açıdan Süryanilerin, millet olarak tanınma sürecinin nizamname ile de değişmediği ve uygulamaların de facto olarak patrikhane tarafindan hayata geçirildiğini söylemek yanlış olmayacaktır.

Hükümet, nizamnameyi resmen onaylamamakla birlikte savaş dönemi şartları itibariyle patrikhanenin iç işleyişine de doğrudan müdahalede bulunmak istememiştir. Böyle bir politikanın benimsenmesinde, Süryani Patrikhanesi'nin Dünya Savaşı ve sonrasındaki süreçte de devletle çatışmalı bir tavır içine girmemiş olmasının etkili olduğu söylenebilir. Patrikhane tarafından hükümete sunulduğu şekliyle nizamnamenin içeriği ve hükümleri şu şekildedir:

54 Osmanlı Devleti'nin resmî evrakları arasında bulunmayan nizamname metninin bir nüshası Mardin Kırklar Kilisesi'nde bulunmaktadır ve ilk defa 1954 yılında Mustafa Emil Elöve tarafından yayımlanmışıır. Elöve'nin makalesinde Süryaniler ve nizamname hakkında verdiği bilgiler için bkz. Elöve, “Türkiye'de Din İmtiyazları”, s. 239-261. Nizamname metni, Elöve'den naklen daha sonra başka araştırmacılar tarafından da yayımlanmıştır. Mehmet Şimşek, "Süryani Kadim Ortodoks Kilisesi Patrikhane Nizamnamesi”, Sosyal Bilimler Araştırma Dergisi (SBArD), III/6 (2005), s. 725-742; Murat Bebiroğlu, Osmanlı Devleti’nde Gayrimüslim Nizamnameleri (İstanbul: Akademi Matbaası, 2008), s. 190-213. Bizim aşağıda nizamnamenin içeriğine yönelik atıflarımız da bu çalışmalarda yayınlanan nizamname metnine dayanmaktadır. Nizamname hakkında ayrıca bkz. Dinno, "The Syrian Orthodox Christians”, s. 66; Akyüz, Osmanl Devleti’nde Süryani Kilisesi, s. 143-144, Belge No: 134-135.

55 Elöve, “Türkiye'de Din İmtiyazları”, s. 260-261. 


\section{Nizamnamenin İçeriği}

Nizamnameye göre Süryani Patriği eskiden beri olduğu şekilde "Antakya Patriği” adıyla anılmaya devam edilecekti. Patriklik merkezi de yine Mardin Sancağı'na bağlı Deyru’z-zafaran Manastırı olacaktı. Süryani Kadîm Patriği gerek Osmanlı Devleti topraklarındaki gerekse Hindistan, Amerika ve diğer bölgelerdeki tüm Süryani kiliselerinin mutlak reîsi olarak kabul edilecekti. ${ }^{56}$ Patriği, Osmanlı topraklarında yaşayan Süryani din adamları seçeceklerdi. ${ }^{57}$ Patrik seçilme yaşı ve patriklik şartları ile birlikte yeni bir patrik seçimi sırasında uygulanacak olan prosedür ayrıntılı olarak açıklanmaktayd $1 .{ }^{58}$ Patriğin en temel vazifesi, nizamname hükümlerine uymak ve nizamnamenin tam anlamıyla uygulanmasını takip etmekti. ${ }^{59} \mathrm{Bu}$ çerçevede patrik Süryaniler hakkında en geniş yetkiye sahip olan kişiydi. ${ }^{60}$ Kendisine bağlı din adamları üzerinde de patriğin mutlak otoritesi bulunmaktayd $1 .{ }^{61}$

Başkent İstanbul'da daha önce kurulmuş olan patrik vekilliği devam ettirilecekti. Bu göreve getirilecek olan kişi, milletin güvendiği birisi olacak ve Türkçe bilmesi de zorunlu olacaktır. ${ }^{62}$ İstanbul Patrik Vekili olacak kişinin seçimi de patriğin seçiminde olduğu gibi yine belli bir prosedür çerçevesinde yürütülecektir. ${ }^{63}$

Ortodoks Süryani Kadîm mezhebine ait dini rütbeler ve ünvanlar eskiden olduğu gibi kullanılmaya devam edilecekti. Din adamı olmak isteyenler, patrikhaneye bağlı manastır ve okullarda eğitim almak mecburiyetindeydiler. Patrik, kendisine bağlı olan din adamlarının tamamının üzerinde yetkiye sahip olan tek liderdi. Bir bölgeye atanacak olan din adamları, o bölge halkının oyları ve onayıyla seçilmek zorundaydı. Ayrıca görev bölgesine giden kişi, ahalinin işlerini yürütmek için bölgede bir cemaat meclisi oluşturacaktı. ${ }^{64}$

56 Süryani Kadîm Milleti Nizamnâme-i Umûmîsi, m. 1.

57 Süryani Kadîm Milleti Nizamnâme-i Umûmîsi, m. 2.

58 Süryani Kadîm Milleti Nizamnâme-i Umûmîsi, m. 3-9.

59 Süryani Kadîm Milleti Nizamnâme-i Umûmîsi, m. 10.

60 Süryani Kadîm Milleti Nizamnâme-i Umûmîsi, m. 11.

61 Süryani Kadîm Milleti Nizamnâme-i Umûmîsi, m. 12-13.

62 Süryani Kadîm Milleti Nizamnâme-i Umûmîsi, m. 16.

63 Süryani Kadîm Milleti Nizamnâme-i Umûmîsi, m. 17-19.

64 Süryani Kadîm Milleti Nizamnâme-i Umûmîsi, m. 23-34. 
Milletin işlerini yürütmek üzere patrikhanede iki meclis teşkil edilecekti. Bu meclislerden birincisi "Meclis-i Muhtelit" (Karma Meclis) adıyla altısı sivil altısı din adamı olmak üzere toplam on iki üyeden oluşacaktı. Patriğin başkanlık edeceği bu meclisin üyeleri üç yılda bir yenilenecektir. ${ }^{65}$ Meclisin temel vazifeleri; patrikhaneye bağlı kilise ve manastırların vakıflarını ve patrikhanenin ait gelir giderleri kontrol etmek, millete ait okulların idaresini ve geliştirilmesini sağlamaktır. ${ }^{66}$ İkinci meclis, "Meclis-i Umumi" (Genel Meclis) adıyla oluşturulacaktır. İsminden de anlaşılacağı üzere bu meclisin üye sayısı ve yapısı daha geniştir. Meclis üyeleri üç kısımdan oluşacaktır: Birinci Kısım; görevde bulunan metropolit ve episkopos seviyesindeki tüm üst düzey din adamlarıdır. İkinci Kısım; her taşra bölgesinden gelecek ikişer din adamı ve sivilden oluşan yerel temsilcilerdir. Üçüncü Kısım ise Meclis-i Muhtelit'in tüm üyeleridir. ${ }^{67}$ Meclis-i Umumi de patrikhane işlerinin düzenlenmesi, tüm kilise ve manastırlar ile okulların işleyişi ve ihtiyaçlarının karşılanmasıyla birlikte Süryani milletine ait tüm dini ve sivil işlerden sorumludur. ${ }^{68}$ $\mathrm{Bu}$ meclisin başkanı da yine patriktir. Mecliste yapılan görüşmeler bir deftere kaydedilir ve ilgililere patrik tarafından iletilir. ${ }^{69}$

Ayrıca nizamnamede milletin hem dini hem de genel eğitimi için okullar açılacağı, var olan okulların da "yeni eğitim şartlarına göre" düzenleneceği belirtilmekteydi. ${ }^{70}$ Bunlarla birlikte patrikhane, milletin ihtiyaç ve isteklerini karşılayacak bu işleri yapabilmek için milletten yıllık bir vergi toplayacaktı. Herkesin gelirine göre alınacak olan bu vergi ${ }^{71}$ ile birlikte patrikhane, uygulanan çeşitli dini merasimler için de belli ücretler almaya devam edeceği gibi ${ }^{72}$ tüm kilise ve manastırların vakıf gelirlerinin yıllık yüzde onluk kısmı da yine patrikhaneye verilecekti. ${ }^{73}$

65 Süryani Kadîm Milleti Nizamnâme-i Umûmîsi, m. 42. Meclis üyelerinin seçim şekilleri de nizamnamede belirtilmiştir, m. 43-45.

66 Süryani Kadîm Milleti Nizamnâme-i Umûmîsi, m. 46-50.

67 Süryani Kadîm Milleti Nizamnâme-i Umûmîsi, m. 51.

68 Süryani Kadîm Milleti Nizamnâme-i Umûmîsi, m. 52.

69 Süryani Kadîm Milleti Nizamnâme-i Umûmîsi, m. 53.

70 Süryani Kadîm Milleti Nizamnâme-i Umûmîsi, m. 56-57.

71 Süryani Kadîm Milleti Nizamnâme-i Umûmîsi, m. 59.

72 Süryani Kadîm Milleti Nizamnâme-i Umûmîsi, m. 61.

73 Süryani Kadîm Milleti Nizamnâme-i Umûmîsi, m. 62. 


\section{Türkiye Cumhuriyeti'ne Geçiş Sürecinde Süryaniler ve Süryani Patrikhanesi}

İçeriğinden de Ermeni Milleti Nizamnamesi örnek alınarak hazırlandığı belli olan Süryani Milleti Nizamnamesi hükümet tarafından onaylanmadan Birinci Dünya Savaşı çıkmıştı. Hükümet de muhtemelen savaş şartlarını gerekçe göstererek nizamnameyi onaylayıp yürürlüğe koymamıştı. Bununla birlikte bu durum Süryani Patrikhanesi ile hükümet arasında herhangi bir çatışmaya sebebiyet vermemişti. Savaşs sırasında Süryani toplumu ile devlet arasında çeşitli tartışmalar yaşanmakla birlikte - önceki dönemlerde olduğu gibi - patrikhane doğrudan Osmanlı Devleti ile karşı karşıya gelmemişti. Ermenilerle Osmanlı Devleti arasında yaşanan problemler kısmen Süryanilerle ilişkilere de yansımış, Ermenilerin bölgeden göç ettirilmesi ve o sırada yaşanan çatışmalar sırasında Ermenilerle birlikte bazı Süryaniler de hem çatışmalarda yer almışlar hem de Ermenilerin yanında onlar da göç ettirilmişlerdi. Ancak bu olaylar bütün Süryanilerin devletle karşı karşıya gelmesine neden olmadığı gibi patrikhane de devletle çatışmalı bir tavır içerisine girmemişti. Bu dönemde en büyük problemler Osmanlı Devleti'nin resmen tanımadığı Nasturi Patrikhanesi ile yaşanmıştı. ${ }^{74}$ Nasturilerle yaşanan problemler de Süryani Kadîm Kilisesi'ni ilgilendiren bir durum değildi. Özellikle 1917 yılında patrik seçilen İlyas Şakir, ${ }^{75}$ Süryani Patrikhanesi'nin ve Süryani toplumunun devletle ilişkilerini daha da yakınlaştırmasını sağlamıştı. İlyas Şakir göreve geldiği sırada devam etmekte olan savaş boyunca hükümetle herhangi bir çatışmaya girmediği gibi, Mondros Mütarekesi sonrası yaşanan işgallere karşı Osmanlı Devleti yanlısı bir tavır sergilemiş, Millî Mücadele sırasında da Mustafa Kemal Paşåyı ve Kuva-yı Milliye’yi desteklemişti. ${ }^{76} 1919$ yılında Mardin'deki patriklik

74 Bülent Özdemir, Süryanilerin Dünü Bugünü (Ankara: Türk Tarih Kurumu Yayınları, 2014), s. 98-102. Ayrıca Bülent Özdemir’in, Paris Barış Konferansı ve Lozan görüşmeleri sırasında Süryanilerle yaşanan problemler olarak anlattığı hadiselerin çoğunluğu da yine aslında Nasturilerle ilgilidir. Özdemir, Süryanilerin Dünü Bugünü, s. 178-200.

75 İlyas Şakir Efendi'nin patrikliğe tayininin onaylandığına dâir irâde müsveddesi; $B O A, M V$. nr. 246/98.

76 Patrik İlyas Şakir Efendi’nin Mondros Mütarekesi sonrası faaliyetleri ve patriklik süreci hakkında bkz. Mustafa Oral, "Mardin'in Son Süryani Kadim Patriği Mor İgnatios İlyas Şakir Efendi (1867-1932)", Makalelerle Mardin IV - Önemli Simalar - Dini Topluluklar, haz. İbrahim Özcoşar (İstanbul: Mardin Tarihi İhtisas Kütüphanesi Yayını, 2007), s. 269297; Naures Atto, Soner Önder, "Geçiş Döneminde (1918-1926) Süryani Ortodoks Kilisesi Önderliği ve Patrikhane'nin Türkiye’den Taşınması Üzerine”, Mardin Tebliğleri: Mardin ve Çevresi Toplumsal ve Ekonomik Tarihi Konferansı, çev. Altuğ Yılmaz, ed. Emre Ayvaz, Altuğ Yılmaz (İstanbul: Hrant Dink Vakfi Yayınları, 2013), s. 195-200. 
merkezinden İstanbul'a gelen İlyas Şakir Efendi, yaklaşık 3 yıl İstanbul'da kalmış, İstanbul'da bulunduğu süre boyunca da Osmanlı Devleti lehine beyânlarda bulunmaya devam etmişti. 1922 yılında Mardin'e dönmek için İstanbul'dan ayrıldığında Ankara'ya uğramış ve bir süre de Ankara'da kalmıştı. Ankara’da iken Mustafa Kemal Paşa ile de görüşmüş ve basına da yine Türkiye lehine açıklamalar yapmıştı. Bu dönemdeki en önemli açılkaması 9 Şubat 1923 tarihinde İleri gazetesinde yayımlanan, Celal Nuri (İleri)'nin kendisiyle yaptığı bir röportajda söyledikleriydi. Lozan Konferansı devam ederken yaptığı bu açıklamayla İlyas Şakir, Süryanilerin Türkiye'de "azınlık" statüsü talep etmediklerini ifade ediyor hatta böyle bir statüyü protesto ettiğini söylüyordu. İfadeleri tam olarak şöyleydi:

"Ne milletim, ne de ben asla ve kat'a hukûk-1 ekalliyet diye Avrupa'nın icâd et-
diği imtiyâzâtı ne iddiâ etdik, ne ediyoruz, ne de ebediyyen edeceğiz! Bu fuzûli
talepde bulunanları protesto ederim. Biz, kendimizi ekalliyet telakki etmeyiz.
Ekseriyyet ve daha doğrusu umûmiyyet olan bütün Türklerin hukûkunu istiyo-
ruz, bu hukûka zaten sahibiz ve Türklerin bütün vazâif ve mükellefiyetleriyle de
mükellefiz."

Aynı açıklamasında İlyas Şakir, Mondros Mütarekesi'nden sonra, başta Osmanlı Devleti ile sonra da Ankara Hükümeti ve Mustafa Kemal Paşa ile karşı karşıya gelmiş olan Ermeni ve Rum patrikhanelerini de eleştirerek, yaptıklarının yanlış olduğunu ifade ediyordu. Bu mülakatıyla yakın tarihlerde Adliye Vekâleti'ne yaptığı bir müracaatta da İlyas Şakir, Süryani kilise ve manastırlarının evkafıyla birlikte patrikhane tarafından tayin edilecek vekillere bırakılmasını talep etmişti. Ayrıca hükümetin resmî yatılı okullarına her sene Süryani fukarasından iki öğrencinin ücretsiz kabul edilmesi, Lice'de bulunan ve Ermenilere ait olup o sırada boş bulunan Ak Kilise'nin kendilerine verilmesi ve daha önce patriklik makamına ödenmekte olan aylık 50 liranın ödenmeye devam edilmesi de patriğin diğer talepleriydi. ${ }^{78}$ Hükümet, patriklik için ödenen meblağın devamının sağlanacağını ifade etmekle birlikte diğer hususlarda kesin bir karar almamış, vekillere bırakılması istenen kilise ve manastırların nerelerde olduklarının ayrıntılı olarak bildirilmesini istemişti. $^{79}$

77 “Muhterem Bir Patrik”, İleri, nr. 1803, 9 Şubat 1923, s. 1-2.

78 Adliye Vekâleti'nden İcrâ Vekilleri Heyeti Riyâseti’ne 7 Mart 1339 (1923) tarihli tezkire; Başbakanlık Cumburiyet Arşivi (BCA), Yer nr: 108, 706, 4 Fon Kodu: 30,10,0,0 lef 1.

79 İcrâ Vekilleri Heyeti'nden Adliye Vekâleti'ne 17 Mart 1339 (1923) tarihli tezkire; BCA, Yer nr: 108, 706, 4 Fon Kodu: 30,10,0,0 lef 2. 
Patrik, talepleri tam olarak karşılanmasa da Lozan'ı takip eden yıllarda hükümetin politikaları ile uyumlu bir tavır sergilemeye devam etmişti. Patriğin İleri gazetesinde yer alan azınlık hukukuna dâir sözlerinin, Lozan Antlaşması'ndan sonra Türkiye'nin Süryanileri azınlık olarak tanımamasının gerekçeleri arasında bulunduğu da düşünülebilir. Ayrıca patrikle birlikte birçok Süryani önde geleni "azınlık" tanımının dışında kalmalarının doğru olduğu görüşündeydiler. Fakat bu düşünceleri bir süre sonra değişmeye başlayacaktı. Musul meselesi dolayısıyla bölgede yaşanan çatışma ve karışıklıklar ilerleyen süreçte Süryanileri de etkilemişti. 1924 yılında meydana gelen Nasturi İsyanı ve ertesi yıl çıkan Şeyh Sait İsyanı’na Nasturilerle birlikte Süryanilerden de katılan ve destek verenler bulunmaktaydı. Özellikle Şeyh Sait isyanına bölgedeki bazı Kürtlerle birlikte kimi Süryani ve Nasturilerin desteği Türkiye'yi ciddi sıkıntılarla karşı karşıya bırakmıştı. Fakat gerek Patrik İlyas Şakir gerekse patrikliğe bağlı din adamlarının çoğu isyanlara karşı çıkmışlar ve devlet yetkilileriyle birlikte hareket etmişlerdi. Bununla birlikte Süryani toplumu içerisinde bu tür hareketlere destek verenler giderek artmaktaydı. 1926 yılı Mart ayında Mardin ve civarında Süryani ve Ézidilerin katıldığı bir isyan daha yaşanacaktı. Bu karışıklıklar arasında Patrik İlyas Şakir 1925 yılında Mardin'den Halep'e (bazı kaynaklara göre Kudüs'e) gitmiş ve vefatına kadar bir daha Türkiye’ye dönmemişti. Bir süre sonra da İngiliz mandası altında olan Irak' in tâbiiyetine girmesi, İlyas Şakir Efendi’nin yaşanan son olaylarda Süryanilerin zarar gördüğünü düşündüğü ancak Türk Hükümeti ile bir çatışmaya girmemek için de Türkiye'yi terk ettiği şeklinde yorumlanmıştı. Yine aynı dönemde çıkarılan Tekke, Zaviye ve Türbelerin Kapatılması ile ilgili kanunun da patriğe, görevini yapmakta zorlanacağını düşündürdüğü iddia edilmişti. Gerçek sebep ne olursa olsun, Patrik İlyas Şakir 1925 yılı itibariyle Türkiye'den ayrılmış, tâbiiyyet değişikliğinden dolayı da 1931 yılında Türkiye vatandaşlı̆̆ından çıkarılmıştı. 1932 yılında Hindistan’a yaptığı bir ziyaret sırasında orada vefat etmiş, vefatına kadar da Süryani Patrikliği ünvan ve görevini sürdürmüştü. ${ }^{80}$

Patriğin vefatından önce, patrikhane yetkilileri tarafından patriklik merkezinin Türkiye'den taşınmasıyla ilgili çalışmalar da başlatılmıştı. 1932 yılı Ocak ayında Humus'ta toplanan Süryani din adamları kongresinde, Osmanlı Devleti tarafından onaylanmamakla birlikte Süryani Kilisesince uygulanmakta olan Süryani

80 Erdoğan, “20. Yüzyılın İlk Yarısında Türkiye'deki Süryaniler” s. 119-129. Atto ve Önder, patriğin kendi rızasıyla Türkiye'den ayrılmadığını, 1924 yılında sürgün edildiğini belirtirler. Patrik, bu yılda Kudüs'e gitmiş, üç yıl orada kaldıktan sonra da Hindistan'a geçmişti. Atto, Önder, "Geçiş Döneminde (1918-1926) Süryani Ortodoks Kilisesi”, s. 200-201. 
Milleti Nizamnamesi'ndeki, patriklik merkezinin Deyru’z-zafaran Manastırı olduğu maddesi değiştirilmişti. ${ }^{81}$ İlyas Şakir’ in vefatından sonra, 1933 yılında Suriye Metropoliti Mor Severiyos Efrem Barsavm'ın patrik olması üzerine de patriklik merkezi Humus’a taşınmıştı. Patriklerin Türkiye Cumhuriyeti vatandaşı olma zorunluluğu bulunduğundan, İlyas Şakir’in vatandaşlıktan çıkması gibi yeni patrik Barsavm da Türkiye vatandaşı olmadığı için patriklik Türkiye sınırlarında kalsaydı zaten patrik Türkiye tarafından resmen tanınmayacak ve görevine başlayamayacaktı. Bu yüzden resmî olarak da patriklik merkezinin Türkiye'de kalmasının bir anlamı bulunmamaktaydı. Patrik Efrem Barsavm’n 1957 yılında vefatına kadar Humus'ta kalan patriklik, Barsavm'dan sonra seçilen Patrik III. Yakup tarafından 1959 yılında Şam’a taşınmıştı. O günden günümüze kadar da Süryani Patrikhanesi, kadîm ve resmî statüsünü vurgulayan "Antakya Patrikliği" ismiyle Şam’da bulunmaya devam etmektedir. ${ }^{82}$

\section{Sonuç}

Osmanlı Devleti'nin idaresine girdikleri dönemden itibaren Ermeni milletine bağlı bir topluluk olarak kabul edilen Süryaniler, Tanzimat döneminden itibaren kendileri de ayrı bir millet olarak tanınmak için uzun uğraşlar vermişlerdi. Bu uğraşlardan resmî bir netice elde edemeseler de Süryanilerin, özellikle 19. yüzyıl sonlarından itibaren de facto olarak ayrı bir millet şeklinde faaliyetlerini sürdürdüğü anlaşılmaktadır. Bununla birlikte Osmanlı idaresinin son yıllarında Süryanilerin durumuyla ilgili bu karmaşı durumun, Cumhuriyet dönemine de yansıdığı aşikârdır. Osmanlı Devleti'nden Türkiye Cumhuriyeti'ne geçişle birlikte devlet nazarında Süryanilerin idaresi hususunda temel manada bir değişim yaşanmadığı görülmektedir. Osmanlı Devleti’nde "millet sistemi”" çerçevesinde, Ermeni milletine bağlı bir topluluk olarak kabul edilen Süryaniler, Cumhuriyet'le birlikte de ayrı bir "azınlık" toplumu olarak tanınmamışlardır. Lozan Antlaşması'nın imzalanma sürecinde, azınlık statüsüne Süryanilerin de genel anlamda sıcak bakmadıkları bilinmektedir. Bu durum Süryanilerin temelde devletle problem yaşamak istememelerinden kaynaklandığı gibi, Süryaniler açısından azınlık tanımının bazı yerel problemlere sebebiyet vereceği de düşünülmekteydi. Süryanilerin Doğu Anadolu şehirlerinde, özellikle 19. yüzyılda büyük problemler yaşadıkları Müslüman Kürt ve Arap unsurlarla bir arada yaşamaya

81 Elöve, “Türkiye'de Din İmtiyazları”, s. 260.

82 Dolabani, Antakya Süryani Kadim (Ortodoks) Patriklerinin Özgeçmişi, s. 4. 
devam edecek olmaları, bazı Süryanilerin azınlık sisteminin dışında kalmalarının doğru olacağını düşünmelerine neden olmuştur. Zira Süryanilerin "azınlık" olarak bir arada yaşadıkları diğer unsurlardan farklı haklara sahip olacakları düşüncesinin, yerelde ahali arasında eski huzursuzlukların devam etmesine neden olacağı düşünülmüştür. Ancak bu "iyi niyetli” düşünceler de uzun süre devam etmemiştir. Azınlık statüsünün dışında kalmak Süryanileri eğitimden dinî hayatın sürdürülmesine kadar birçok alanda değişik problemlerle karşı karşıya bırakmıştır. Türkiye'de yaşayan Süryaniler için hâlen devam etmekte olan bu sorunlar aslında Lozan Antlaşması'ndan birkaç yıl sonra açı şekilde görülmeye başlanmış ancak devlet tarafindan uygulamaya konulan çeşitli çalışmalara rağmen konuyla ilgili çözümleyici bir netice elde edilememiştir.

Öz — Osmanlı Devleti'nde Süryaniler idarî olarak Ermeni Patrikhanesi'ne bağlı bulunmaktaydılar. Fatih Sultan Mehmet'in İstanbul'u fethi sonrası teşkilatlandırılan "Millet Sistemi”nde gayrimüslim milletler olarak sadece Rumlar, Ermeniler ve Yahudiler kabul edilmekteydiler. Rumlar ve Ermeniler dışındaki diğer Hristiyan gruplar, idarî olarak Rum veya Ermeni Patrikhanesi'ne bağlanmışlardı. Süryaniler, Ermeni Patrikhanesi'nin sorumluluğunda olan gruplardandılar. Bu idarî yap1 19. yüzyıla kadar devam edecek, bu yüzyıldan itibaren klasik millet sistemi değişime uğramaya başlayacaktı. Devlet, Rum - Ermeni ve Yahudiler dışındaki bazı Hristiyan toplulukları da ayrı birer millet olarak tanımaya ve mevcut "milletler" önceki dönemlerden farklı olarak anayasal bazı haklar vermeye başlayacaktı. Süryaniler bu dönemde böyle bir hak elde etmeyi başaramamışlar ancak 19. yüzyıl ortalarında İstanbul'da kendilerine ait bir temsilcilik açmışlardı. Fakat bu durum, Süryanilerin devletle olan ilişkilerini doğrudan kendilerinin sürdürecekleri anlamına gelmemekteydi. Ermeni Patrikhanesi hâlâ Süryanilerle devlet arasında aracılık konumuna devam etmekteydi. Bu durum sonraki yıllarda Ermeni - Süryani çekişmelerini daha da artıracaktı. Süryaniler Osmanlı Devleti içinde yaşayan diğer gayrimüslim milletler gibi resmî statüde kendi adlarıyla ayrı bir millet olarak tanınma sürecine ancak 1914 yılında girebilmişlerdi. Bu tarihte hükümete sunulan "Süryani Kadîm Milleti Nizamnamesi” ile Süryani Milleti, Rum, Ermeni ve Yahudi milletlerinin 19. yüzyıl sonlarında yürürlüğe girmiş olan nizamnameler ile kazandıkları anayasal hakları, onlardan yaklaşı 50 yıl sonra elde etmek için resmen müracaatta bulunmuş oluyordu. Bu makalede Süryani milletinin Osmanlı idaresinde yaşadığı idarî süreç, Ermeni Patrikhanesi’ne bağlı olmalarının Süryaniler açısından olumsuz etkileri, Ermeni Patrikhanesi'nden ayrılma çabaları, bu çabalar sırasında yaşanan Ermeni - Süryani çekişmeleri ve 1914 yılında hükümete sunulan nizamname ile talep ettikleri statü incelenecektir. Nizamnamenin içeriği ve maddeleri hakkında ayrıntılı açıklamalar yapılarak, diğer gayrimüslim milletlerin nizamnameleri ile arasındaki benzerlik ve farklılıklar vurgulanacaktır.

Anahtar kelimeler: Millet Sistemi, Süryaniler, Ermeni Patrikhanesi, Birinci Dünya Savaşı. 


\section{Bibliyografya}

\section{Arşiv Belgeleri}

Başbakanlık Osmanlı Arşivi (BOA), Sadâret Mektûbî Kalemi Mühimme Odası (A.MKT. MHM.) nr. 609/36.

BOA, Sadâret Evrak Kalemi (A.VRK.) nr. 140/19.

BOA, Bâb-1 Âlî Evrak Odası (BEO.) nr. 660/49438.; 4230/317250.

BOA, Dâhiliye Nezâreti Sicill-i Nüfus Tahrirat Kalemi (DH.SN.THR.) nr. 60/49.

BOA, Dâhiliye Nezâreti Muhâberât ve Tensîkat Müdüriyeti (DH.EUM.MTK.) nr. 74/51.

BOA, Tahrîrât-1 Hâriciye Odası (HR.TH.) nr. 166/20.

BOA, Meclis-i Vükelâ Mazbataları (MV.) nr. 182/25.; 246/98.

BOA, Yıldız Esas Evrâkı (Y.EE.) nr. 38/71.

BOA, Yıldız Perâkende Evrakı Adliye ve Mezâhib Nezâreti Maruzâtı (Y.PRK.AZN.) nr. $15 / 1$.

Başbakanlık Cumhuriyet Arşivi (BCA), Yer nr: 108, 706, 4 Fon Kodu: 30,10,0,0.

BCA, Yer nr: 108, 706, 4 Fon Kodu: 30,10,0,0 lef 2.

\section{Gazeteler}

İleri, nr. 1803, 9 Şubat 1923.

\section{Yayınlanmış Eserler}

Akdemir, Samuel: “Geçmişte ve Günümüzde Türkiye'deki Süryani Kilisesi”, Dinler Tarihi Araştırmaları - III (Sempozyum, 09-10 Haziran 2001, Ankara), Hiristiyanlık (Dünü, Bugünü ve Geleceği), Ankara: Dinler Tarihi Derneği Yayınları 2002, s. 9-12.

Akyüz, P. Gabriyel: Deyrulzafaran Manastırinın Tarihi, İstanbul: Resim Ofset - Matbaacrlik A. Ş. 1998.

: Mardin İlinin Merkezinde, Civar Köylerinde ve İlçelerinde Bulunan Kiliselerin ve Manastırların Tarihi, İstanbul: Resim Ofset - Matbaacılık A. Ş. 1998.

.: Osmanlı Devleti’nde Süryani Kilisesi, Mardin: Resim Ofset A. Ş. 2002.

Atto, Naures, Soner Önder: "Geçiş Döneminde (1918-1926) Süryani Ortodoks Kilisesi Önderliği ve Patrikhane’ nin Türkiye'den Taşınması Üzerine”, Mardin Tebliğleri: Mardin ve Çevresi Toplumsal ve Ekonomik Tarihi Konferansı, çev. Altuğ Yılmaz, ed. Emre Ayvaz, Altuğ Yılmaz, İstanbul: Hrant Dink Vakfı Yayınları 2013, s. 195-206. 
Bayburt, Deniz: Türk Tarihi’nde Süryaniler (1880-1938) (Yayımlanmamış Doktora Tezi) Ankara: Gazi Üniversitesi Sosyal Bilimler Enstitüsü, 2009.

Bebiroğlu, Murat: Osmanlı Devleti’nde Gayrimüslim Nizamnameleri, İstanbul: Akademi Matbaası 2008.

Beydilli, Kemal: II. Mahmut Devrinde Katolik Ermeni Cemâati ve Kilisesinin Tanınması (1830), yay. Şinasi Tekin, Gönül Alpay Tekin, Harvard: Harvard Üniversitesi Yakındoğu Dilleri ve Medeniyetleri Bölümü Yayını 1995.

Bilge, Yakup: Geçmişten Günümüze Süryaniler, İstanbul: Zvi-Geyik Yayınları 2001.

Braude, Benjamin: "Foundation Myths of the Millet System", Christians and Jews in the Ottoman Empire: The Functioning of a Plural Society, c. I: The Central Lands, ed. Benjamin Braude, Bernard Lewis, New York - London: Holmes \& Meier Publishers 1982, s. 69-88.

Bulduk, Abdulgani Fahri: Diyarbakır Valileri, yay. haz. Eyyüp Tanrıverdi, Ahmet Taşğın, İstanbul: Medrese Yayınları 2007.

Çiçek, Mustafa: Tanzimat Sonrasında Osmanlı Devleti’nde Süryanî Cemaati (Yayımlanmamış Yüksek Lisans Tezi) Sakarya: Sakarya Üniversitesi Sosyal Bilimler Enstitüsü, 2003.

Dinno, Khalid S.: The Syrian Orthodox Christians in the Late Ottoman and Post-Ottoman Periods: Crisis and Revival (Yayımlanmamış Doktora Tezi) Toronto: Department of Near and Middle Eastern Civilizations, University of Toronto, 2015.

Dolabani, Hanna: Antakya Süryani Kadim (Ortodoks) Patriklerinin Özgeçmişi, çev. Gabriyel Akyüz, ed. İbrahim Özcoşar, Hüseyin H. Güneş, İstanbul: Mardin Tarihi İhtisas Kütüphanesi Yayını 2006.

Elöve, Mustafa Emil: “Türkiye'de Din İmtiyazları: Bölüm II - Ermeniler”, Ankara Üniversitesi Hukuk Fakültesi Dergisi, XI/1-2 (1954), s. 184-280.

Ercan, Yavuz: Kudüs Ermeni Patrikhanesi, Ankara: Türk Tarih Kurumu Yayınları 1988.

Erdoğan, Haşim: 20. Yüzyılın İlk Yarısında Türkiye’deki Süryaniler (Yayımlanmamış Doktora Tezi) Kayseri: Erciyes Üniversitesi Sosyal Bilimler Enstitüsü, 2013.

Güllü, Ramazan Erhan: "1895-1896 Ermeni İsyanlarının Osmanlı Vilayet İdaresine Etkileri: Halep Örneği”, OTAM (Ankara Üniversitesi Osmanlı Tarihi Araştırma ve Uygulama Merkezi Dergisi), 32 (Güz 2012), 2013, s. 1-33.

.: Ermeni Sorunu ve Istanbul Ermeni Patrikhanesi (1878-1923), Ankara: Türk Tarih Kurumu Yayınları 2015.

: “1895-1896 Ermeni İsyanlarında Batılı Devletlerin Osmanlı Devleti’ne Yönelik Tutumlarına Bir Örnek: Enis Paşa’nın Diyarbakır ve Halep Valiliklerine Karşı Tepkiler”, Ermeni Ayaklanmaları (1894-1909) Sempozyumu (23 Ocak 2014, Ankara) Bildirileri, Ankara: Türk Tarih Kurumu Yayınları 2015, s. 179-197. 
..: "Bulgar Eksarhlığı’nın Kuruluşu ve Statüsü”, Gaziantep Üniversitesi Sosyal Bilimler Dergisi (GAUN-JSS), 17/1 (2018), s. 350-361.

Günel, Aziz: Türk Süryaniler Taribi, Diyarbakır: y. y. 1970.

Kenanoğlu, M. Macit: Osmanlı Millet Sistemi - Mit ve Gerçek, İstanbul: Klasik Yayınları 2007.

Kieser, Hans-Lukas: Iskalanmış Barış: Doğu Vilayetleri’nde Misyonerlik, Etnik Kimlik ve Devlet 1839-1938, çev. Atilla Dirim, İstanbul: İletişim Yayınları 2010.

Koluman, Aziz: Ortadoğu'da Süryanilik (Dini - Sosyal - Kültürel Hayat), Ankara: Avrasya Stratejik Araştırmalar Merkezi Yayınları 2001.

Konortas, Paraskevas: "İstanbul Rum-Ortodoks Patrikhanesi ile Osmanlı Yönetiminin Birlikte Yaşamı (1453-1923)”, İdea Politika, 4 (Güz 1999), s. 64-72.

: "Tarihi Uzlaşma’dan Entente Cordial'e?: İstanbul Ortodoks Patrikhanesi ile Osmanlı İdaresi Arasında İdeolojik ve Siyasi Amaç Birliği (15. Yüzyıl Ortası - 16. Yüzyıl Sonu)", çev. Yaman Aksu, Tarihî, Siyasi, Dinî ve Hukuki Açıdan Ekümenik Patrikhane, ed. Cengiz Aktar, İstanbul: İletişim Yayınları 2011, s. 27-69.

Macar, Elçin: "Mardin'deki Amerikalı Protestan Misyonerler ve Kurumları", Mardin Tebliğleri: Mardin ve Çevresi Toplumsal ve Ekonomik Tarihi Konferansı, ed. Emre Ayvaz, Altuğ Yılmaz, İstanbul: Hrant Dink Vakfı Yayınları 2013, s. 113-125.

Molitor, Joseph: Kildaniler ve Doğu Süryani Kilisesi, çev. Erol Sever, İstanbul: Yaba Yayınları 2004.

Oral, Mustafa: "Mardin'in Son Süryani Kadim Patriği Mor İgnatios İlyas Şakir Efendi (1867-1932)", Makalelerle Mardin IV - Önemli Simalar - Dini Topluluklar, haz. İbrahim Özcoşar, İstanbul: Mardin Tarihi İhtisas Kütüphanesi Yayını 2007, s. 269-297.

Özcoşar, İbrahim: Bir Yüzynl Bir Sancak Bir Cemaat: 19. Yüzyzlda Mardin Süryanileri, İstanbul: Beyan Yayınları 2008.

: "Papalığın Müdahalesi ve Süryani Kiliselerinde Bölünme: Keldanî ve Süryani Katolik Patriklikleri”, Süryaniler ve Süryanilik - I. Kitap, haz. Ahmet Taşğın, Eyyüp Tanrıverdi, Canan Seyfeli, Ankara: Orient Yayınları 2005, s. 267-296.

.: "Osmanlı Devleti'nde Millet Sistemi ve Süryani Kadimler", Süryaniler ve Süryanilik - II. Kitap, haz. Ahmet Taşğın, Eyyüp Tanrıverdi, Canan Seyfeli, Ankara: Orient Yayınları 2005, s. 209-237.

: "Süryani-Müslüman İlişkileri”, Makalelerle Mardin IV - Önemli Simalar - Dini Topluluklar, haz. İbrahim Özcoşar, İstanbul: Mardin Tarihi İhtisas Kütüphanesi Yayını 2007, s. 197-217.

: "Separation and Conflict: Syriac Jacobites and Syriac Catholics in Mardin in the Eighteenth and Nineteenth Centuries", Byzantine and Modern Greek Studies, 38/2 (2014), s. 201-217. 
..: “Osmanlı'da Hristiyan Cemaatler Arası İlişkiler: Ermeni-Süryani Örneği”, Mukaddime, 5/2 (Güz-2014), 2015, s. 1-14.

Özdemir, Bülent: Süryanilerin Dünü Bugünü, Ankara: Türk Tarih Kurumu Yayınlar1 2014.

Öztemiz, Mutay: II. Abdülhamit'ten Günümüze Süryaniler, İstanbul: Ayrıntı Yayınları 2012.

Parpola, Simo: "National and Ethnic Identity in the Neo-Assyrian Empire and Assyrian Identity in Post-Empire Times", Journal of Assyrian Academic Studies, 18/2 (2004), s. 5-49.

Sarı, Gökhan: Ermeni Meselesi Işı̆̆ında Süryaniler: Tartışılan Bir Köken, Eleştirilen Bir Politika ve Unutulan Bir Değer, Ankara: Barış Kitabevi 2013.

Sarıyıldız, Gülden: "Osmanlı Devleti'nde Protestan Ermeni Milleti ve Kilisesinin Tanınması”, Yakın Dönem Türkiye Araștırmaları, İstanbul Üniversitesi Atatürk İlkeleri ve Inkılâp Tarihi Enstitüsü Dergisi, 1/2 (2002), s. 249-267.

Seyfeli, Canan: "Osmanlı Devlet Salnamelerinde Süryaniler (1847-1918)", Süryaniler ve Süryanilik - I. Kitap, haz. Ahmet Taşğın, Eyyüp Tanrıverdi, Canan Seyfeli, Ankara: Orient Yayınları 2005, s. 49-140.

: “Osmanlı Devleti'nde Gayrimüslimlerin İdari Yapısı: Süryani Kadim Kilisesi Örneği”, Süryaniler ve Süryanilik - I. Kitap, haz. Ahmet Taşğın, Eyyüp Tanrıverdi, Canan Seyfeli, Ankara: Orient Yayınları 2005, s. 251-265.

: "Millet Sistemi ve Osmanlı Devlet Salnamelerinde Süryani Kadim Patrikliği (18471918)”, Sosyal Bilimler Araştırma Dergisi (SBArD), 15/29 (Bahar, 2017/1), s. 17-45.

Sofuoğlu, Ebubekir, İlke Nur Akvarup: “Osmanlı Devleti’nde Millet Sistemi ve Süryaniler”, Akademik Incelemeler Dergisi, 7/1 (2012), s. 71-87.

Şimşek, Mehmet: Süryaniler ve Diyarbakır, İstanbul: Chiviyazılar Yayınevi 2003.

.: "Süryani Kadim Ortodoks Kilisesi Patrikhane Nizamnamesi", Sosyal Bilimler Araştırma Dergisi (SBArD), III/6 (2005), s. 725-742.

Taşğın, Ahmet: "Süryani Kadim Ortodoks Kilisesinde Yenileşme Çabaları: Deyru'l-Zafaran Manastırında Patriklik Matbaası", Süryaniler ve Süryanilik - IV. Kitap, haz. Ahmet Taşğın, Eyyüp Tanrıverdi, Canan Seyfeli, Ankara: Orient Yayınları 2005, s. 1-26.

Taylor, William: Narratives of Identity: The Syrian Orthodox Church and the Church of England, 1895-1914, Newcastle upon Tyne: Cambridge Scholars Publishing 2013.

Trigona-Harany, Benjamin: The Ottoman Süryânîfrom 1908 to 1914, Piscataway-NJ: Gorgias Press 2009. 
